\title{
Evaluation of Low-Velocity Impact Tests of Solid Steel Billet onto Concrete Pads, and Application to Generic ISFSI Storage Cask for Tipover and Side Drop
}

Prepared by

Monika C. Witte

Tien F. Chen

Gerald C. Mok

Susarla S. Murty

Larry E. Fischer

March 1997

एాSுSி

2 Fission Energy and Systems Safety Program

Lawrence Livermore National Laboratory 


\section{DISCLAIMER}

This document was prepared as an account of work sponsored by an agency of the United States Government. Neither the United States Government nor the University of California nor any of their employees, makes any warranty, express or implied, or assumes any legal liability or responsibility for the accuracy, completeness, or usefulness of any information, apparatus, product, or process disclosed, or represents that its use would not infringe privately owned rights. Reference herein to any specific commercial product, process, or service by trade name, trademark, manufacturer, or otherwise, does not necessarily constitute or imply its endorsement, recommendation, or favoring by the United States Government or the University of California. The views and opinions of authors expressed herein do not necessarily state or reflect those of the United States Government or the University of California, and shall not be used for advertising or product endorsement purposes.

This report has been reproduced directly from the best available copy.

Available to DOE and DOE contractors from the Office of Scientific and Technical Information

P.O. Box 62, Oak Ridge, TN 37831

Prices available from (615) 576-8401, FTS 626-8401

Available to the public from the

National Technical Information Service

U.S. Department of Commerce

5285 Port Royal Rd.,

Springfield, VA 22161 


\section{Evaluation of Low-Velocity Impact Tests of Solid Steel Billet onto Concrete Pads, and Application to Generic ISFSI Storage Cask for Tipover and Side Drop}

Manuscript Date: March 1997

Prepared for

U.S. Nuclear Regulatory Commission 


\section{Contents}

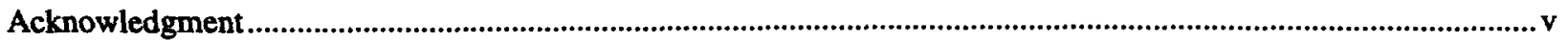

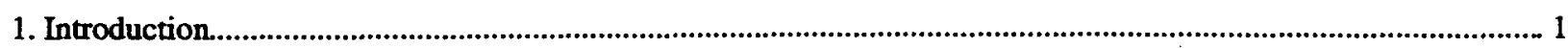

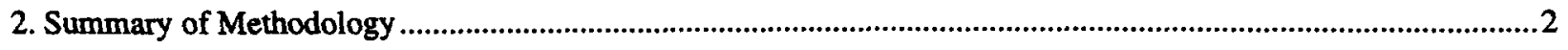

3. Rigid Body Motion of Billet Tests ..................................................................................................................... 3

4. Finite Element Model Representation of Billet Side Drop and Tipover Tests......................................................... 3

4.1. Material Model Representation in the Finite Element Model ........................................................................... 4

4.2. Steel Billet Impact Finite Element Simulation Results..................................................................................... 9

5. Full Size "Generic" Storage Cask Side Drop and Tipover Finite Element Simulations ........................................10

5.1. Selection and Modeling of "Generic" Cask ..........................................................................................................

5.2. Finite Element Tipover and Side Drop Simulation Results............................................................................. 10

6. Application of FEM Results to Future Static Analysis of Basket ..........................................................................11

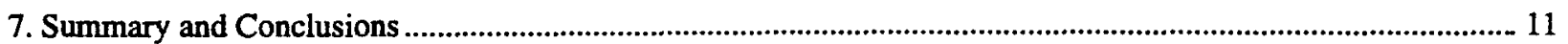

\section{Tables}

Table 1. Condition of Concrete Pad for Side and Tipover Drop Tests........................................................................ 7

Table 2. Soil Elastic Parameters ...................................................................................................................................... 8

Table 3. Maximum Billet Side Drop Acceleration Test vs. Simulation........................................................................ 9

Table 4. Maximum Billet Tipover Acceleration Test vs. Simulation............................................................................... 9

Table 5. ISFSI Generic Cask Tipover and Side Drop Analysis Results.................................................................... 11 


\section{Figures}

Figure 1. Finite element model of steel billet side drop and tipover onto concrete pad and soil ............................. 12

Figure 2. Test \#3, 18" billet side drop, test data from channel A3 ..................................................................... 13.

Figure 3. Test \#5, 18" billet side drop, test data from channel A3 ................................................................. 14

Figure 4. Test \#10, 18" billet side drop, test data from channel A3 ................................................................... 15

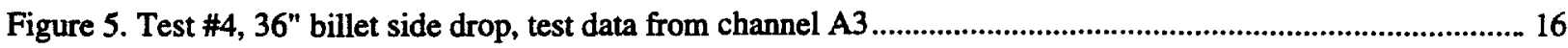

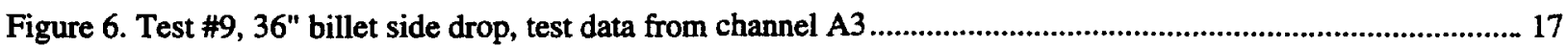

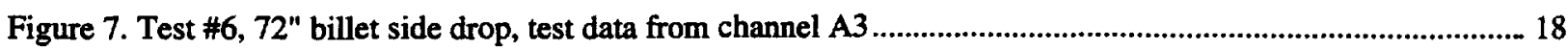

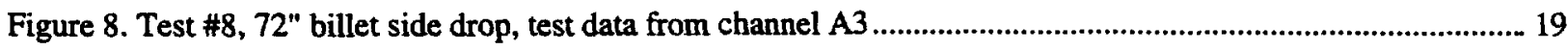

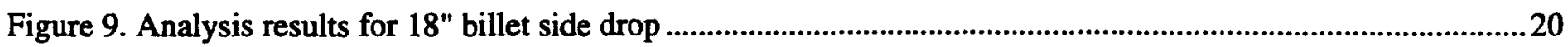

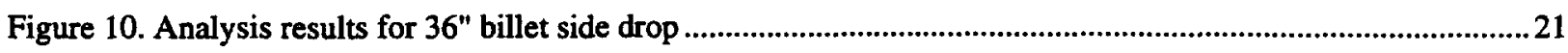

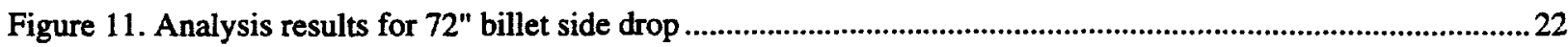

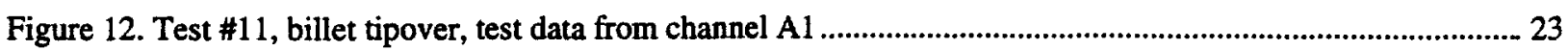

Figure 13. Test \#12, billet tipover, test data from channel A1 ...................................................................24

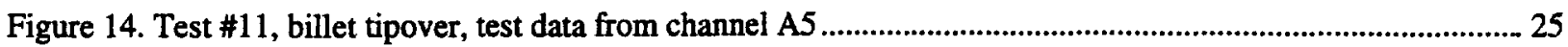

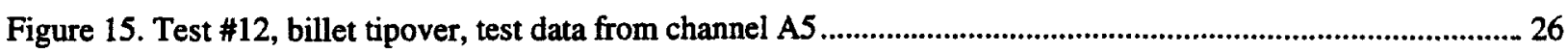

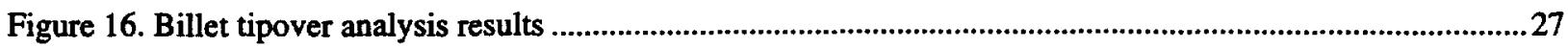

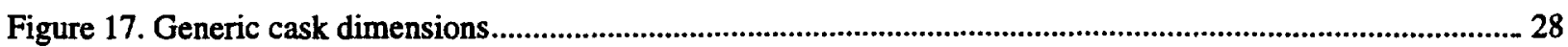

Figure 18. Finite element model of "generic" storage cask ..............................................................................29

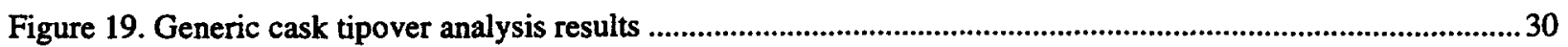

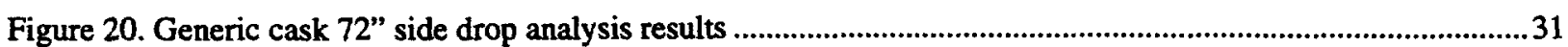




\section{Acknowledgment}

This report was prepared by the Lawrence Livermore National Laboratory and was funded by the Spent Fuel Project Office, Office of Nuclear Material Safety and Safeguards, U.S. Nuclear Regulatory Commission. The authors wish to thank David Tang of the NRC for his support and encouragement. 


\section{Evaluation of Low-Velocity Impact Tests of Solid Steel Billet onto Concrete Pads, and Application to Generic ISFSI Storage Cask for Tipover and Side Drop}

\section{Introduction}

Spent Fuel Storage Casks intended for use at Independent Spent Fuel Storage Installations (ISFSIs) typically are evaluated during the application and review process for low-energy impacts representative of possible handling accidents including tipover events. In the past, the analyses involved in these evaluations have assumed that the casks dropped or tipped onto an unyielding surface, a conservative and simplifying assumption. Since 10 CFR Part $72^{1}$, the regulation imposed by the Nuclear Regulatory Commission (NRC), does not require this assumption, applicants are currently seeking a more realistic model for the analyses and are using analytical models which predict the effect of a cask dropping onto a reinforced concrete pad, including energy absorbing aspects such as cracking and flexure. In order to develop data suitable for benchmarking these analyses, the NRC has conducted several series of drop-test studies.

The tests described in this report were primarily intended to determine the response characteristics of concrete pads during tipover and side impacts of a solid steel billet onto the pads. This series of tests is fourth in a program of tests funded by the NRC; all four series of tests address issues of impact involving spent fuel storage casks. The first series was performed in March 1993 by Sandia National Laboratories (SNL) and involved five end-drops of a billet, nearly identical to the one used in the present series, onto a variety of surfaces from a height of 18 inches. The second series of tests was performed between July and October 1993, and involved four end-drops of a near-full-scale empty Excellox $3 \mathrm{~A}$ cask onto a full-scale concrete pad and foundation, or onto an essentially unyielding surface, from heights ranging from 18 inches to 60 inches, and was conducted by the British Nuclear Fuels Limited in Winfrith, England. (Two of the drops in the second series were sponsored by Electric Power Research Institute.) The third test series was performed in September 1993 by SNL, and involved eight further end-drop tests of the billet onto concrete pads. These pads were cast on engineered fill resting on undisturbed soil; billets were dropped from heights ranging from 18 inches to 6 feet. The first three series of tests are described in a Sandia report by P. McConnell, et. al. ${ }^{2}$

The fourth test series included twelve drops of a solid steel cylindrical billet onto a reinforced concrete pad resting on undisturbed soil, and was conducted by Lawrence Livermore National Laboratory (LLNL) in February 1996. The size of the billet was selected to match the billet used in the Series 1 and 3 tests; it is roughly a 1/3-scale model of a spent fuel storage cask (the linear dimension is scaled). The dimensions of the concrete pad were selected to match the concrete pads used in the Series 1 and 3 tests; however, the outside pad dimension is somewhat larger because tests in this series are primarily side drops and earlier tests were end-drops. The concrete pads are roughly 1/3-scale models of the symmetry section of a hypothetical ISFSI concrete storage pad, including the reinforcing steel and gravel within the concrete.

\footnotetext{
${ }^{1}$ United States Code of Federal Regulations Title 10, Part 72.

${ }^{2}$ McConnell, P., et al. “Test Report, Drop Tests Onto Concrete Pads for Benchmarking Response of Interim Spent Fuel Storage Installations," Sandia National Laboratory, September 1993.
} 
This report is the second of three reports on this fourth test series. The first report ${ }^{3}$ described the tests and provided (1) the raw acceleration-time history results, (2) some velocities and displacements obtained by numerically integrating the acceleration data, and (3) Fourier Transforms to characterize the frequency characteristics of the data. This second report provides an evaluation of the side and tipover results. The end-drop results from the fourth drop test series will be discussed and evaluated in a third report which will address the end-drop results from all four series of drop tests.

This report provides a method to evaluate the test results and a method to apply the results to an analysis of a full-size storage cask. An example application to a "generic" full-size cask is also provided, for tipover and low-velocity side impacts.

\section{Summary of Methodology}

In order to use the test data provided in Reference 3 to evaluate impact loads for a full-size storage cask, a series of steps needs to be taken. A brief summary of the required steps is given here, and is described in greater detail in Sections 3 through 6.

- Step 1: Rigid Body Motion of Billet Tests

The accelerometer data collected and reported in Reference 3 includes unfiltered data for twelve tests. The data must be filtered at an appropriate frequency in order to remove the vibratory component of the noise in the data such that the remaining deceleration represents the rigid body motion of the billet. This effort resulted in a filter frequency of $450 \mathrm{~Hz}$ for the side and tipover impact test data, and is described in Section 3 of this report.

- Step 2: Finite Element Model Representation of Billet Tests

The data collected and filtered in Step 1 is then used to determine the response characteristics of concrete pads during impact in order to develop a material model of the concrete pad to be used for analysis of low-velocity impact conditions. This task involves developing a finite element model of the billet and pad to be used in a series of dynamic analyses simulating the billet test conditions. Based on the series of simulations, a material model of the concrete pad is developed which characterizes the parameter of primary interest, that is, the rigid body g-loads corresponding to those determined in Step 1. This effort is described in Section 4 of this report.

- Step 3: Full Size Storage Cask Side Drop and Tipover Finite Element Simulations

The concrete pad properties developed in Step 2 are then utilized in a finite element simulation of a full-scale "generic" cask dropping sideways and tipping over onto a typical concrete storage pad. The "generic" cask FEM model did not include a detailed model of the basket; rather, a homogeneous basket model representing the appropriate density and approximate overall stiffness was used. This effort is described in Section 5 of this report.

\footnotetext{
3witte, M., et al. "Low Velocity Impact Testing of Solid Steel Billet onto Concrete Pads," Lawrence Livermore National Laboratory, UCRL-ID 126274, March 1997.
} 
- Step 4: Application of Finite Element Results to Future Quasi-Static Analysis of Basket

In order to evaluate the stresses in a secondary structure (such as the basket) resulting from the g-loads predicted by an analysis of the primary structure (the cask), two options are available. One might choose to use the acceleration time history calculated in Step 3, and apply it directly in a dynamic finite element analysis of the basket. Or, the usual choice is to develop a model of the basket and perform a quasi-static analysis of the basket using the peak g-load determined in Step 3. In this case, it is necessary to determine a dynamic amplification factor for the basket. This is discussed in Section 6 of this report.

\section{Rigid Body Motion of Billet Tests}

The purpose of filtering the dynamic test or analysis results of an impacting billet is to extract from the total dynamic response the rigid body or whole-body component of the response. A vibration analysis of the impacting billet and target and a Fourier-spectrum analysis of the impact response were performed. The analyses showed that the dominant frequencies of the rigid body response were lower than all significant natural vibration frequencies of the billet. Therefore, a low-pass filter was used for the filtering. A Butterworth filter was chosen because it produced minimal amplitude distortions. The time delay or phase shift produced by the filter in the filtered signal was eliminated by performing a backward filtering after the normal forward filtering. An 8th order filter was used to provide an adequately sharp cutoff of the high-frequency response. Using the Fourier spectrum of the dynamic response as a guide, the cutoff frequency for filtering the billet drop test results was set at $450 \mathrm{~Hz}$. The cutoff frequency was located below the lowest significant vibration frequency of the billet and near the bottom of a valley of the Fourier spectrum, where the billet response is minimum. The adequacy of the cutoff frequency was confirmed by comparing the Fourier spectra of the filtered and unfiltered responses. The comparison showed that the filtering practically removed high-frequency responses representing the billet free vibrations but none of low-frequency response representing the rigid body motion.

\section{Finite Element Model Representation of Billet Side Drop and Tipover Tests}

A finite element model with the steel billet, concrete pad and the subgrade soil was constructed using the TrueGrid ${ }^{4}$ mesh generator. The model takes advantage of symmetry planes that exist in this drop orientation; thus, only a quarter model is needed for the billet side drop impact analysis. A half model is used for the billet tipover analysis. The finite element model is shown in Figure 1. The impact event is simulated with the nonlinear finite element code DYNA3D ${ }^{5}$. Slide surfaces with voids are placed in between the steel billet and the concrete pad and in between the concrete pad and the subgrade soil. No information regarding the value of coefficient of friction in between those sliding surfaces is available from the test. A coefficient of friction of 0.25 is therefore assumed for both slide surfaces. A non-reflecting boundary condition is also imposed on three faces of the soil model, except on the symmetry face, to better represent the true situation of infinite soil domain with no stress wave reflection from soil medium.

\footnotetext{
4TueGrid, XYZ Scientific Applications, Inc., Livermore, CA.

SWhirley, R. G. "DYNA3D, A Nonlinear, Explicit, Three-Dimensional Finite Element Code for Solid and Structural Mechanics-User Manual, " Lawrence Livermore National Laboratory, UCRL-MA-107254 , Rev. 1, 1993.
} 
The billet side impact is simulated by imposing a uniform initial velocity on the billet; the tipover is simulated by applying an initial rotational velocity to the billet.

\subsection{Material Model Representation in the Finite Element Model}

\section{Steel Billet}

The material of the test billet was ASTM 576 Grade 1045 steel, with a tensile strength of $97 \mathrm{ksi}$ and a yield strength of 60 to $67 \mathrm{ksi}$, per the supplier. This steel billet material property can best be represented by a constitutive model which provides elastoplastic material behavior with isotropic hardening. The yield condition can be written as

$$
\phi=\bar{\sigma}-\sigma_{\mathbf{y}}\left(\bar{\varepsilon}^{\mathbf{p}}\right)
$$

where $\bar{\sigma}$ is the effective stress, $\bar{\varepsilon}^{\mathrm{p}}$ is the effective plastic strain, and $\sigma_{\mathrm{y}}$ is the current yield stress. The hardening law has the form

$$
\sigma_{\mathbf{y}}=\mathbf{k}\left(\varepsilon_{0}+\bar{\varepsilon}^{\mathbf{p}}\right)^{\mathbf{n}}
$$

where $\varepsilon_{0}$ is the initial yield strain given by

$$
\varepsilon_{0}=\left(\frac{E}{k}\right)^{\frac{1}{n-1}}
$$

The values selected for constants in the above expressions which best characterize the billet material are:

$$
\begin{aligned}
& E=30.0 \times 10^{6} \mathrm{psi}, \text { Young's modulus } \\
& \mathrm{k}=140892 \mathrm{psi}, \text { yield stress coefficient } \\
& \mathrm{n}=0.1456253, \text { strain hardening exponent }
\end{aligned}
$$

The terms effective stress, effective plastic strain, yield stress, yield condition, and Young's modulus are defined in solid mechanics and plasticity text books such as reference 6 . The yield stress coefficient and strain hardening exponent are parameters described in the DYNA3D User's Manual for the specific material model employed.

\section{Concrete Pad}

The concrete pad is modeled using a constitutive model based on a concrete which was developed by LLNL for the Shippingport Station Decommissioning Project in 1988. The model was developed for the concrete fill in the reactor pressure vessel/neutron shield tank. At the time that the model was developed, the Stanford Research Institute was contracted to measure the required properties using samples of the particular concrete grout used in the Shippingport project. Because the average compressive strengths of the Shippingport concrete-grout and the

\footnotetext{
${ }^{6}$ Mendelson, Alexander, "Plasticity: Theory and Application," Macmillan, New York, 1968.
} 
concrete pads for this drop test study were similar, a modification to the Shippingport concrete model was used for the drop test concrete pad. In the present simulation, no steel reinforcement has been explicitly modeled, even though the pads did in fact contain reinforcing steel. The model was judged to behave satisfactorily, due in part to the stiffness of the concrete model itself.

Material Model 16 has the capability of modeling strain-rate effects for the yield strength via the use of a load curve multiplier. Material damage and failure phenomenon in materials such as concrete can be modeled through the use of a two-curve concept. The two yield-vs.-pressure curves are defined as the upper, or undamaged, curves, represented by

$$
\sigma_{\max }=\mathbf{a}_{0}+\frac{\mathbf{P}}{\mathbf{a}_{1}+\mathbf{a}_{2} \mathbf{P}},
$$

where:

$$
\begin{aligned}
& \sigma_{\max }=\text { the material yield stress at the undamaged state } \\
& \text { P } \quad \text { pressure } \\
& a_{0}, a_{1}, a_{2}=\text { material constants that characterize the yield-vs.-pressure relationship }
\end{aligned}
$$

and the lower, or failed (damaged), curve is represented by

$$
\sigma_{\text {failed }}=\mathbf{a}_{0 \mathrm{f}}+\frac{\mathbf{P}}{\mathbf{a}_{1 \mathrm{f}}+\mathbf{a}_{2} \mathbf{P}},
$$

where:

$$
\begin{aligned}
& \sigma_{\text {fiiled }}=\text { the material yield stress at the damaged state } \\
& a_{06}, a_{1 f}, a_{2}=\text { material constants that characterize the yield-vs.-pressure relationship } \\
& \text { in the damaged state. }
\end{aligned}
$$

After defining those two curves and an appropriate "damage" scale factor, $\eta$, versus the effective plastic strain in this material model, then the following equation is used

$$
\sigma_{\text {yield }}=\sigma_{\text {failed }}+\eta\left(\sigma_{\max }-\sigma_{\text {failed }}\right)
$$

to describe either a hardening or a softening phenomenon as commonly observed in the concrete material according to the amount of plastic strain produced in the material. The pressurevolumetric strain relationship of the material is treated independent of its deviatoric behavior and can be described by using a tabulated equation-of-state form. The volumetric strain, $\varepsilon_{\mathrm{v}}$, is defined as the natural logarithm of the relative volume: $\varepsilon_{\mathrm{v}}=\ln \left(\mathrm{V} / \mathrm{V}_{0}\right)$, and is negative in compression. 
The following material constants are used to define the constitutive relationship, using Mode II.B of Material Model 16:

$$
\begin{aligned}
& p=2.09675 \times 10^{-4} \mathrm{lb} \cdot \mathrm{sec}^{2} / \mathrm{in}^{4} \\
& v=.22 \\
& a_{0}=1606 \mathrm{psi} \\
& a_{1}=0.418 \\
& a_{2}=8.35 \mathrm{E}-5 \mathrm{psi}^{-1} \\
& b_{1}=0 \\
& a_{0 f}=0.0 \mathrm{psi} \\
& a_{1 f}=0.385
\end{aligned}
$$

\begin{tabular}{|c|c|}
\hline Effective Plastic Strain & Scale factor, $\eta$ \\
\hline 0.0 & 0.0 \\
\hline .00094 & .289 \\
\hline .00296 & .465 \\
\hline .00837 & .629 \\
\hline .01317 & .774 \\
\hline .0234 & .893 \\
\hline .04034 & 1.0 \\
\hline 1.0 & 1.0 \\
\hline
\end{tabular}

The maximum principal stress at tensile failure is set at an 870 psi cutoff. Since data on strain rate effects were unavailable, a constant load curve multiplier of unity was used. The pressurevolume behavior of the concrete is modeled with a tabulated pressure-vs.-volumetric strain relationship: 


\begin{tabular}{|c|c|}
\hline Volumetric strain $\left(\varepsilon_{\mathrm{v}}\right)$ & Pressure (psi) \\
\hline 0.0 & 0.0 \\
\hline-0.006 & 4600 \\
\hline-0.0075 & 5400 \\
\hline-0.01 & 6200 \\
\hline-0.012 & 6600 \\
\hline-0.02 & 7800 \\
\hline-0.038 & 10000 \\
\hline-0.06 & 12600 \\
\hline-0.0755 & 15000 \\
\hline-0.097 & 18700 \\
\hline
\end{tabular}

The unloading bulk modulus, $\mathrm{K}$, is assumed to be a constant $700 \mathrm{ksi}$ at any volumetric strain.

The material constants that characterize the yield-vs.-pressure relationship for the concrete in the damaged state and the "damage" scale factor are parameters described in the DYNA3D User's Manual for the specific material model employed.

Six concrete pads were poured for the twelve drop tests used in this test series. Each pad was used twice, so for the second test on each pad, the pad had been partially damaged by the previous drop as listed in Table 1. An attempt was made to minimize the effect of the damage on the drop results, by turning the billet by $90^{\circ}$, and by dropping the lower velocity drops prior to the higher velocity. In one case only a higher velocity drop was made first (see Test \# 10) in order to evaluate the effect of the pad cracking on the result.

Table 1. Condition of Concrete Pad for Side and Tipover Drop Tests

\begin{tabular}{|l|l|l|}
\hline \multicolumn{3}{|c|}{ Side Drop Billet Tests } \\
\hline $\begin{array}{l}\text { Test } \\
\text { ID }\end{array}$ & Condition of Pad & Drop Height \\
\hline$\# 3$ & undamaged & $18 "$ \\
\hline$\# 5$ & undamaged & $18 "$ \\
\hline$\# 10$ & $\begin{array}{l}\text { damaged (reused the } \\
\text { pad from test \#9) }\end{array}$ & $18^{\prime \prime}$ \\
\hline$\# 4$ & $\begin{array}{l}\text { damaged (reused the } \\
\text { pad from test \#3) }\end{array}$ & $36 "$ \\
\hline$\# 7$ & undamaged & $36 "$ \\
\hline$\# 9$ & undamaged & $36 "$ \\
\hline$\# 6$ & $\begin{array}{l}\text { damaged (reused the } \\
\text { pad from test \#5) }\end{array}$ & $72 "$ \\
\hline$\# 8$ & $\begin{array}{l}\text { damaged (reused the } \\
\text { pad from test \#7) }\end{array}$ & $72 "$ \\
\hline
\end{tabular}

\begin{tabular}{|l|l|l|}
\hline \multicolumn{3}{|c|}{ Tipover Billet Tests } \\
\hline $\begin{array}{l}\text { Test } \\
\text { ID }\end{array}$ & Condition of Pad & Drop Height \\
\hline$\# 11$ & undamaged & $\begin{array}{l}\text { CG over } \\
\text { comer tip }\end{array}$ \\
\hline$\# 12$ & $\begin{array}{l}\text { damaged (reused the } \\
\text { pad from test \#11) }\end{array}$ & $\begin{array}{l}\text { CG over } \\
\text { corner tip }\end{array}$ \\
\hline
\end{tabular}




\section{Subgrade Soil Representation}

Soil properties vary widely from one place to another; therefore, it is difficult to select a soil model that can cover most situations. In light of its uncertainty, it was decided to use the simple elastic model for the representation of subgrade soil. Bowles ${ }^{7}$ listed some representative ranges of soil values, provided here in Table 2. As can be seen, there is a wide variation of soil properties, even in the elastic range.

Table 2. Soil Elastic Parameters

\begin{tabular}{|l|l|c|}
\hline Subgrade & E, ksi & $v$ \\
\hline Clay & $0.05-6.0$ & $0.1-0.5$ \\
\hline Glacial fill & $1.5-22.0$ & \\
\hline Sand & $1.0-12.0$ & $0.2-0.4$ \\
\hline Sand and Gravel & $7.0-28.0$ & $0.1-0.4$ \\
\hline Loess & $2.0-8.0$ & $0.1-0.3$ \\
\hline Shales & $20.0-2000.0$ & \\
\hline Silt & $0.3-3.0$ & $0.3-0.35$ \\
\hline
\end{tabular}

A few analytical simulations of the billet end-drop on concrete pad, on top of soil were made with varying soil elastic properties. Young's Modulus was varied from a low of $6 \mathrm{ksi}$ to a high of $600 \mathrm{ksi}$ and $v$ was varied from 0.2 to 0.4 . These variations in soil elastic properties produced little differences in the predicted initial 'peak' deceleration of the billet. Preliminary results on billet deceleration are derived from the raw accelerometer data for the three billet end-drops onto concrete pad. Results show that all are within experimental uncertainty band, despite the three very different soil types: (1) decomposed granite-type soil, (2) loam-type soil (both drops were performed at the Sandia test site), and (3) wet clay-type soil at LLNL's Site 300. These results also suggest that the subgrade soil under the concrete pad has a secondary effect on the initial response of the billet. Thus, it was decided that an elastic soil model with

$$
\begin{aligned}
& E=6 \mathrm{ksi} \\
& v=0.3
\end{aligned}
$$

would be used in this simulation.

\subsection{Steel Billet Impact Finite Element Simulation Results}

The analysis results for the steel billet impact simulation include the response calculated by the finite element code at each calculational time step $\left(3.7 \times 10^{-6}\right.$ seconds). The analysis results were filtered using the same filtering technique which was used for the test results: a Butterworth lowpass filter with a cutoff frequency of $450 \mathrm{~Hz}$ was used. (This is an eighth-order Butterworth

${ }^{7}$ Bowles, J. E. Foundation Analysis and Design, 2nd ed., McGraw Hill, 1977, p. 35. 
filter.) The data processing software DADiSP 4.0 was used, both for the analysis data and for the test data. Results are provided in Tables 3 and 4. Plots of selected filtered and unfiltered experimental data are included as Figures 2 through 8 for the side drops and Figures 12 through 15 for the tipovers. Plots of the corresponding analysis results are provided in Figures 9 through 11 for the side drops and in Figure 16 for the tipover.

By applying the "dynamic" material properties listed in the previous section, the steel billet impact simulation results are tabulated below for different billet side drop height.

Table 3. Maximum Billet Side Drop Acceleration Test vs. Simulation

\begin{tabular}{|l|cc|cc|}
\hline Billet drop height & \multicolumn{2}{|c|}{ Test data from channel A3, } & \multicolumn{2}{l|}{$\begin{array}{l}\text { Finite element analysis } \\
\text { simulation, filtered at 450 Hz }\end{array}$} \\
\hline 18 inches (Test \#3) & $108.2 \mathrm{~g}$ & (Fig. 2) & & \\
18 inches (Test \#5) & $86.0 \mathrm{~g}$ & (Fig. 3) & $104.3 \mathrm{~g}$ & (Fig. 9) \\
18 inches (Test \#10) & $125.5 \mathrm{~g}$ & (Fig. 4) & & \\
\hline 36 inches (Test \#4) & $110.0 \mathrm{~g}$ & (Fig. 5) & & \\
36 inches (Test \#7) & not available & & \\
36 inches (Test \#9) & $125.2 \mathrm{~g}$ & (Fig. 6) & & \\
\hline 72 inches (Test \#6) & 206.7 & (Fig. 7) & & \\
72 inches (Test \#8) & 197.0 & (Fig. 8) & $182.6 \mathrm{~g}$ & (Fig. 11) \\
\hline
\end{tabular}

Table 4. Maximum Billet Tipover Acceleration Test vs. Simulation

\begin{tabular}{|c|c|c|c|c|}
\hline Test \# / Channel \# & Test data, & ed at $450 \mathrm{~Hz}$ & $\begin{array}{l}\text { Finite eleme } \\
\text { simulation, }\end{array}$ & $\begin{array}{l}\text { nalysis } \\
\text { red at } 450 \mathrm{~Hz}\end{array}$ \\
\hline Test \#11/ Channel A1 & $237.5 \mathrm{~g}$ & (Fig. 12) & \multirow{4}{*}{\multicolumn{2}{|c|}{$233.1 \mathrm{~g} \quad$ (Fig. 16) }} \\
\hline Test \#12 / Channel A1 & $213.6 \mathrm{~g}$ & (Fig. 13) & & \\
\hline Test \#11/ Channel A5 & $231.5 \mathrm{~g}$ & (Fig. 14) & & \\
\hline Test \#12 / Channel A5 & $213.0 \mathrm{~g}$ & (Fig. 15) & & \\
\hline
\end{tabular}

Tables 3 and 4 show that the finite element simulation results of the billet impact event for three drop heights and one tipover impact using the material properties described are in good agreement with test results. The predicted g-loads are typically (not always) slightly lower than the tested g-loads for the same filter frequency. This could be due to a number of factors, including lack of reinforcing steel in the concrete model, and the fact that the concrete used in the analytical model is representative of 4200 psi compressive strength concrete, whereas the concrete used for the actual test conditions was 4460 psi compressive strength concrete. 


\section{Full Size "Generic" Storage Cask Side Drop and Tipover Finite Element Simulations}

\subsection{Selection and Modeling of "Generic" Cask}

A storage cask using representative dimensions, material properties, and cask weight was selected for this study. The cask selected is referred to in this report as a "generic" cask, and is shown in Figure 17. The "generic" storage cask tipover and side drop were simulated using the concrete and soil material property representations described in Section 4.1 with the DYNA3D finite element code.

The finite element model for the "generic" cask is shown in Figure 18. Only the essential structural members of the cask are included in the model. Components such as weather cover, trunions, and neutron shield are neglected. The basket structure and fuel assemblies are modeled as a solid cylinder which occupies the region within the cask cavity that is occupied by fuel. The weight distribution of the cylinder representing the basket structure follows closely to that of a typical basket with fuel assembly, whereas the stiffness of the cylinder is set at $E=2.8 \times 10^{6} \mathrm{psi}$ to reflect the flexible nature of the basket structure. As can be seen in Figure 18, the basket is modeled in sections in order to facilitate data reduction at various locations along the basket length.

The sliding interfaces are placed between the basket structure and the inner surface of the cask wall, between the cask and the concrete pads, and between the concrete pad and the soil. The concrete pad dimensions used in the simulation are 160 in.-wide, 200 in.-long, and 36 in.-thick. The finite element model takes advantage of the symmetry plane that exists along the axis of the cask. Again, non-reflecting boundary conditions are imposed on all faces of the soil model to prevent artificial stress wave reflections from the boundaries of the soil model.

The cask tipover impact is simulated with DYNA3D by imposing an angular velocity of 1.729 radians/sec to the entire cask body. The center of rotation is set at the edge of the cask bottom. DYNA calculates the initial velocity components associated with each node for this rotational motion.

\subsection{Finite Element Tipover and Side Drop Simulation Results}

The maximum rigid body decelerations are obtained from the simulations for the side drop and tipover of the "generic" cask. The analysis results from these simulations have been filtered with a process similar to the billet analysis filtering process. The cutoff frequency for filtering the generic cask analysis results was set at $350 \mathrm{~Hz}$, because the lowest cask vibration frequency is about $100 \mathrm{~Hz}$ less than the corresponding frequency of the billet. The maximum decelerations averaged through the lid of the cask for the tipover, and through the cask wall for the side drop are listed in Table 5. 
Table 5. ISFSI Generic Cask Tipover and Side Drop Analysis Results

\begin{tabular}{|l|c|l|}
\cline { 2 - 3 } \multicolumn{1}{c|}{} & $\begin{array}{c}\text { Finite element analysis } \\
\text { simulation, filtered at 350 } \mathbf{~ H z}\end{array}$ & Location of reported g's \\
\hline Tipover & $66.7 \mathrm{~g}$ (Fig. 19) & Averaged through the cask lid \\
\hline 72 " side drop & $53.8 \mathrm{~g}$ (Fig. 20) & $\begin{array}{l}\text { Averaged through the cask } \\
\text { wall }\end{array}$ \\
\hline
\end{tabular}

\section{Application of FEM Results to Future Static Analysis of Basket}

In order to apply the g-load calculated for the storage cask body to a secondary structure such as a basket, several options are available. An analyst might take the calculated acceleration time history of the cask body and apply it directly to the secondary structure in a dynamic analysis. Or, an analyst may choose to perform a quasi-static analysis of the secondary structure, in which case a dynamic amplification factor needs to be applied to the static load. In the absence of information about the vibration period of the secondary structure, a dynamic amplification factor of two is appropriate.

\section{Summary and Conclusions}

Twelve tests were performed at LLNL to assess loading conditions on a spent fuel cask for side drops, end drops and tipover events. The tests were performed with a 1/3-scale model billet and a 1/3-scale model concrete pad to benchmark the structural analysis code DYNA3D. The side drop and tipover test results are discussed in this report. The billet and test pad were modeled with DYNA3D using material properties and techniques used in earlier tests. The peak or maximum deceleration test results were within 20 percent of the simulated analytical results. It was concluded that the DYNA3D code is adequately benchmarked for this type of application.

A "generic" or representative cask was modeled with the benchmarked DYNA3D code and evaluated for ISFSI side drop and tipover events. The analytical method can be applied to similar casks to estimate impact loads on storage casks resulting from low-velocity side or tip impacts onto concrete storage pads. 


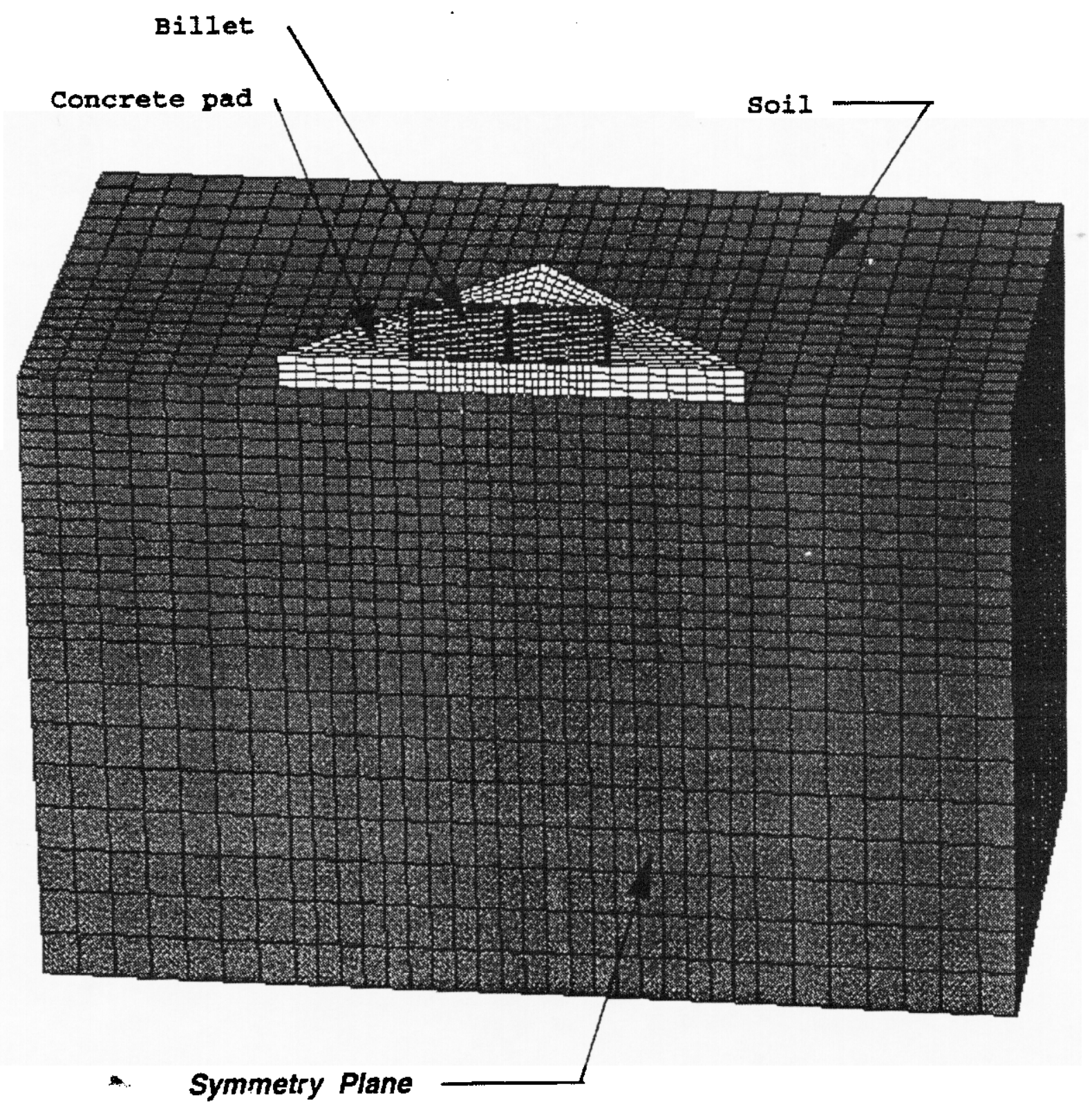

Figure 1. Finite element model of steel billet side drop and tipover onto concrete pad and soil 


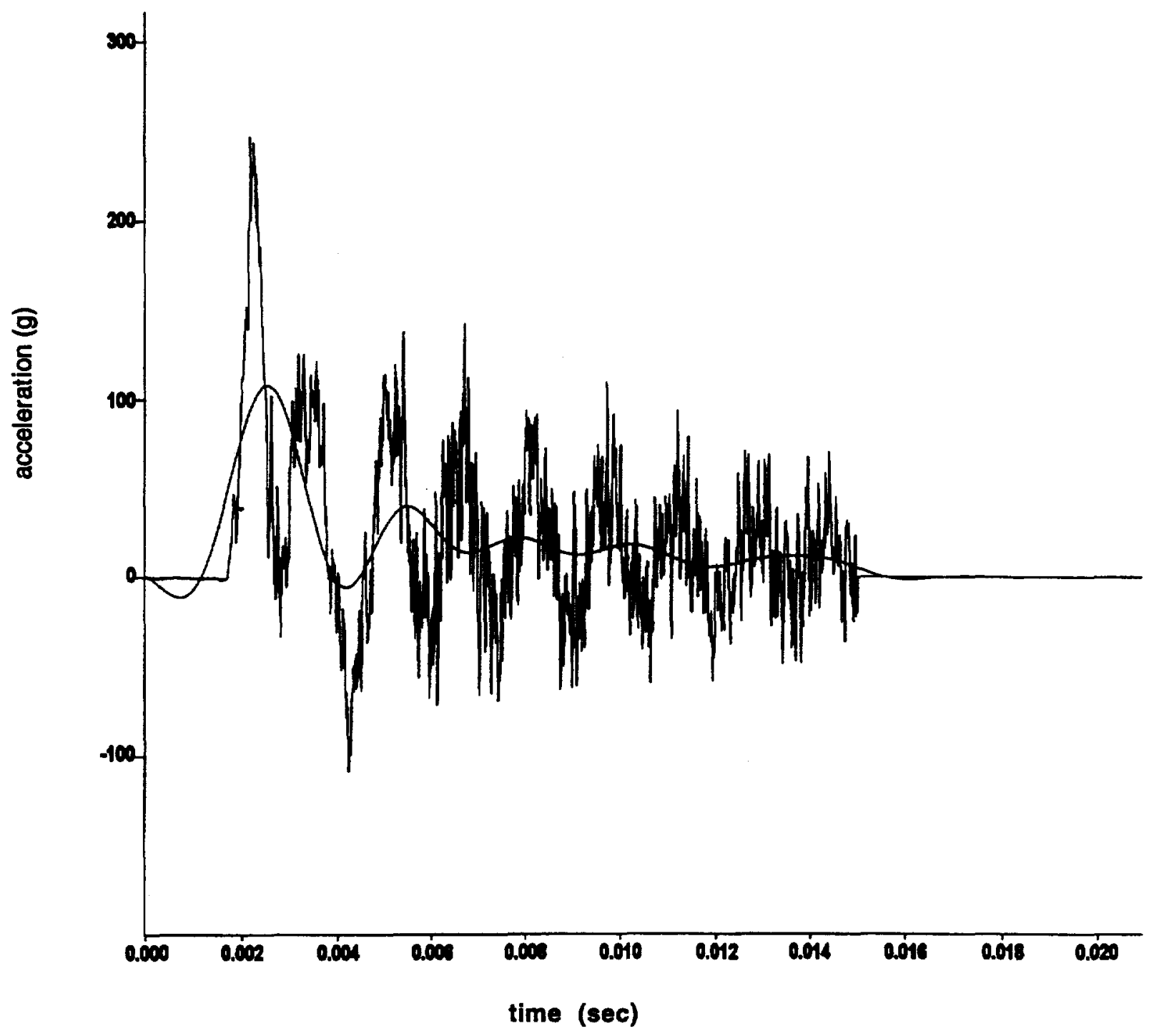

Figure 2. Test \#3, 18" billet side drop, test data from channel A3: unfiltered and filtered at $450 \mathrm{~Hz}$, maximum acceleration $=108.2 \mathrm{~g}$ 


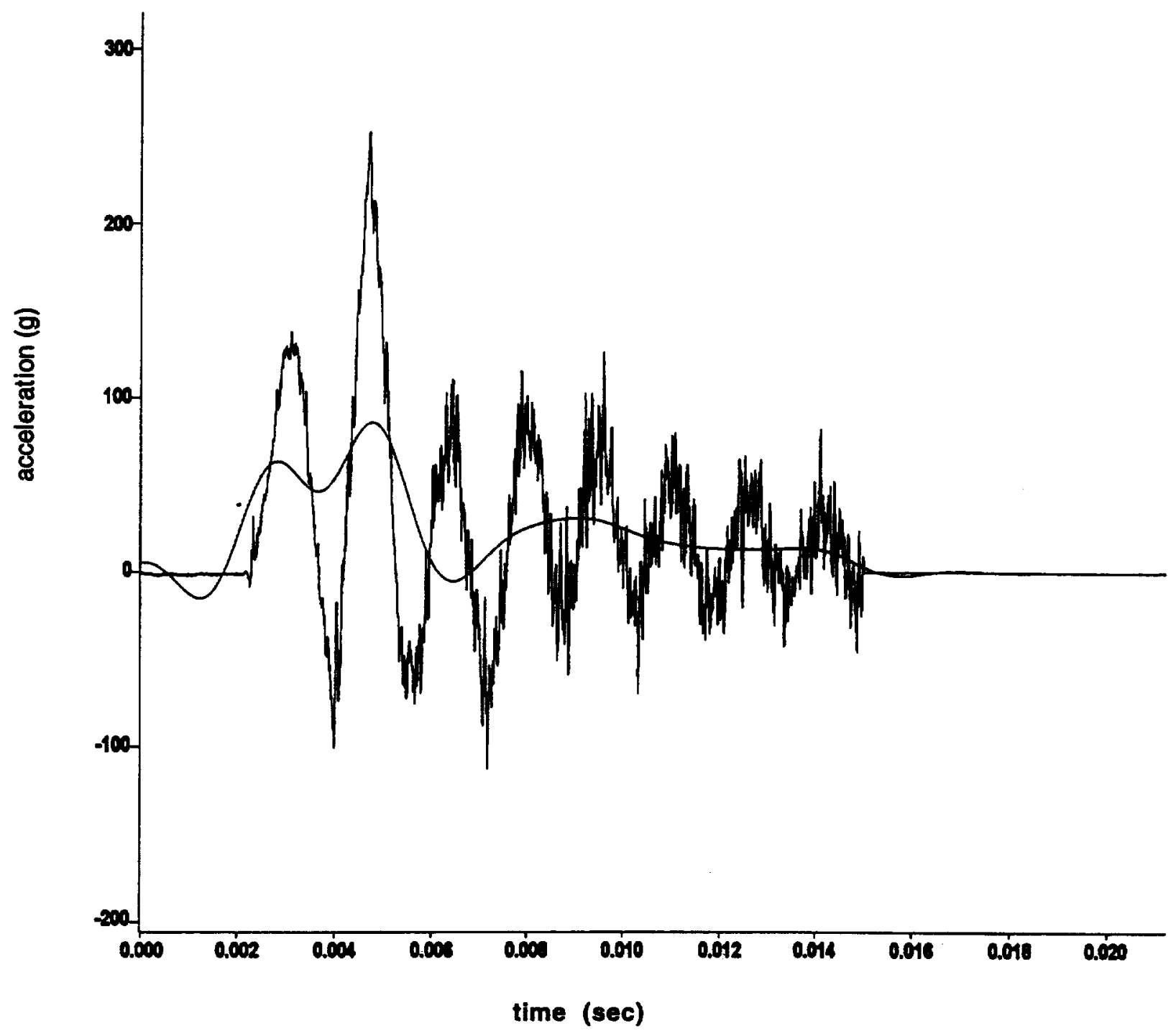

Figure 3. Test \#5, 18" billet side drop, test data from channel A3: unfiltered and filtered at $450 \mathrm{~Hz}$, maximum acceleration $=86.0 \mathrm{~g}$ 


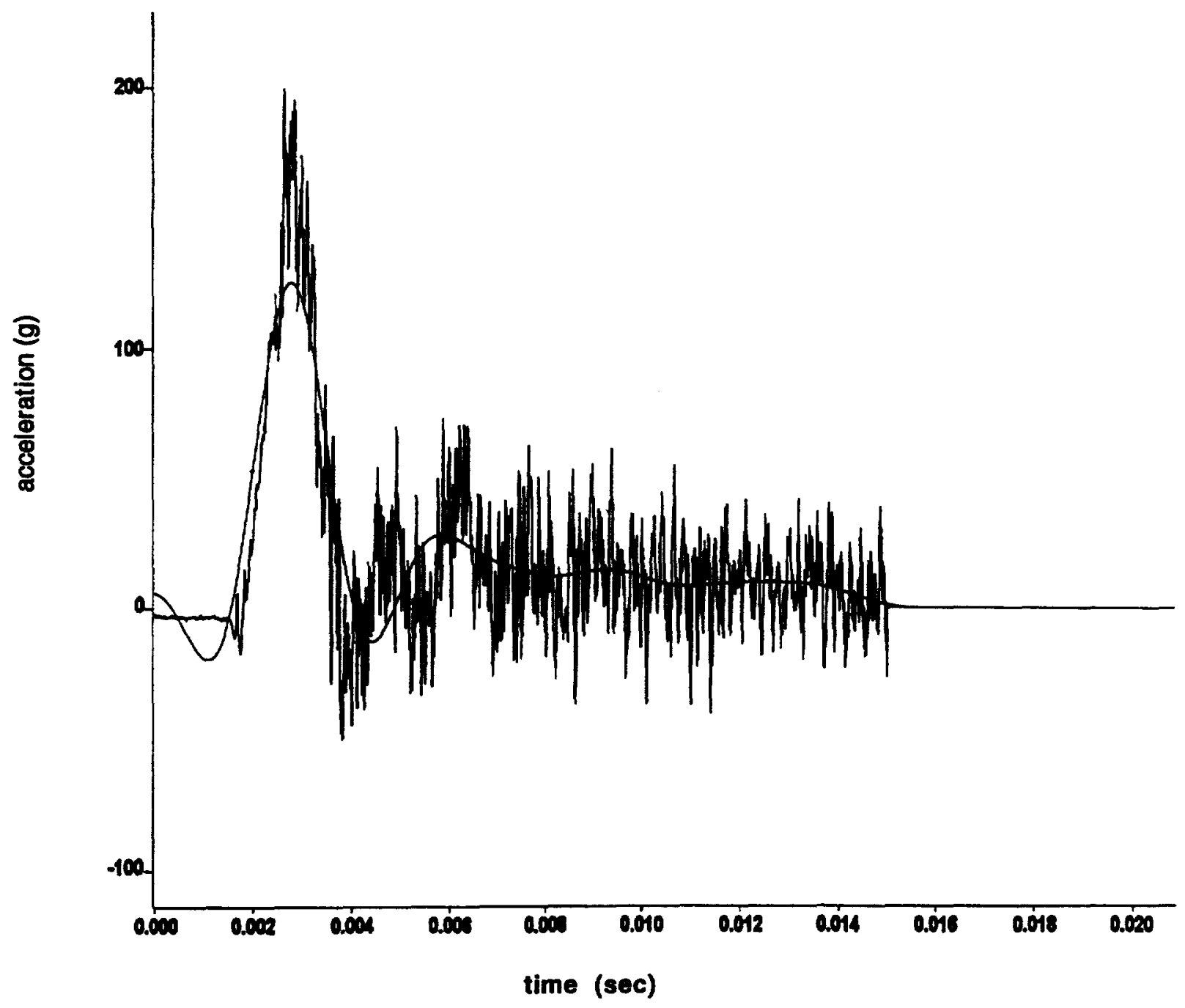

Figure 4. Test \#10, 18" billet side drop, test data from channel A3: unfiltered and filtered at $450 \mathrm{~Hz}$, maximum acceleration $=125.5 \mathrm{~g}$ 


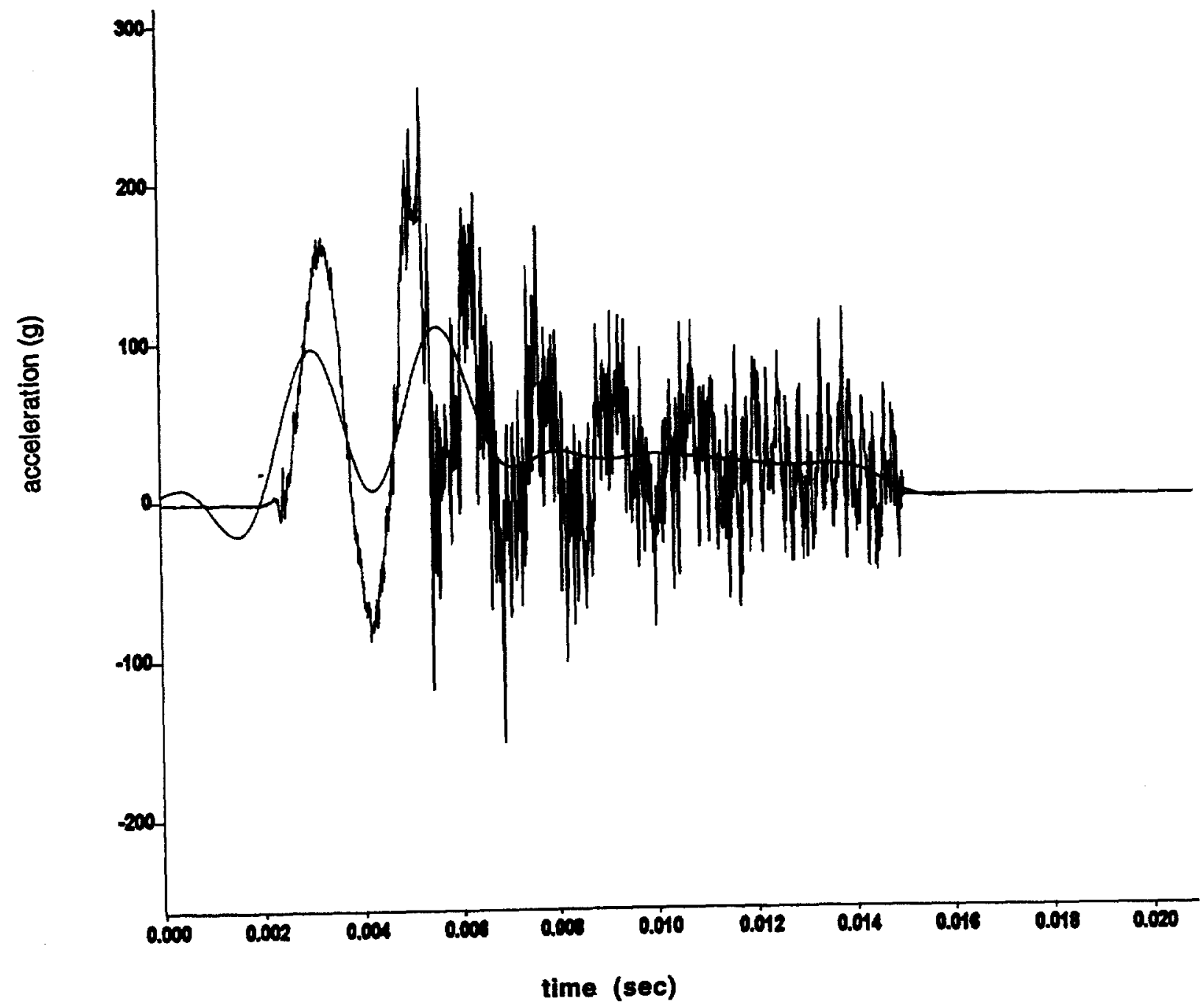

Figure 5. Test \#4, 36" billet side drop, test data from channel A3: unfiltered and filtered at $450 \mathrm{~Hz}$, maximum acceleration $=110 \mathrm{~g}$ 


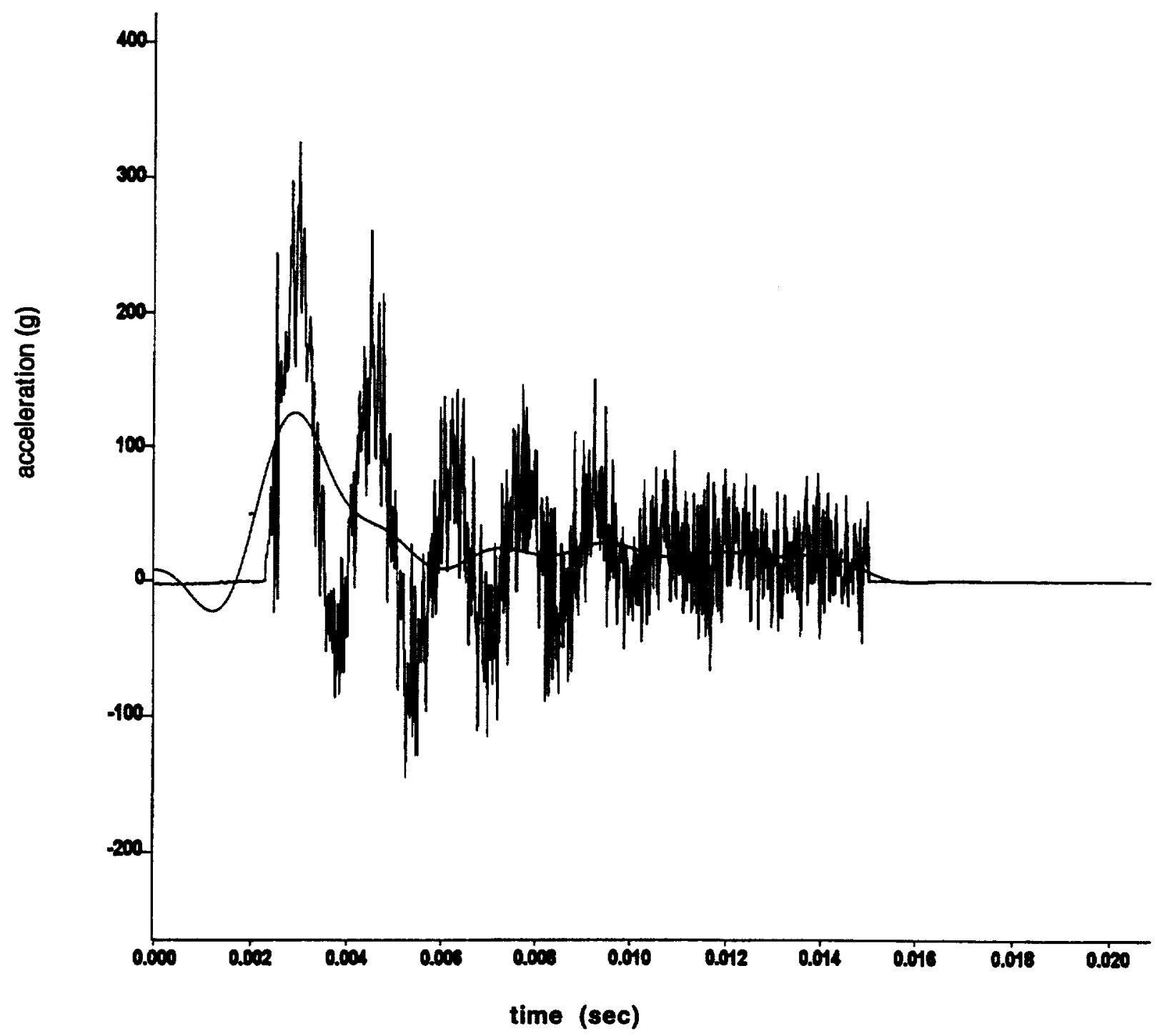

Figure 6. Test \#9, 36" billet side drop, test data from channel A3: unfiltered and filtered at $450 \mathrm{~Hz}$, maximum acceleration $=125.2 \mathrm{~g}$ 


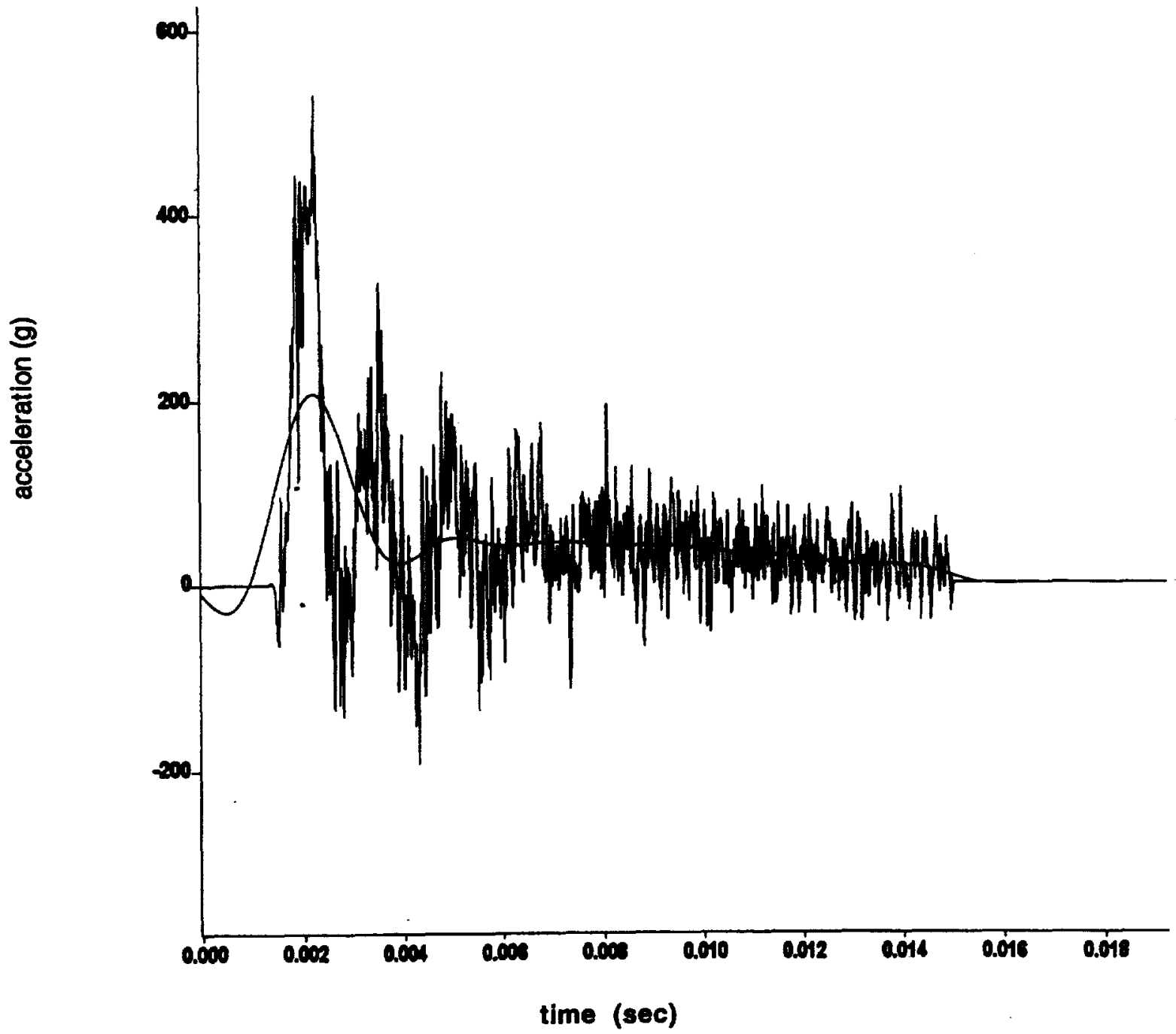

Figure 7. Test \#6, 72" billet side drop, test data from channel A3: unfiltered and filtered at $450 \mathrm{~Hz}$, maximum acceleration $=206.7 \mathrm{~g}$ 


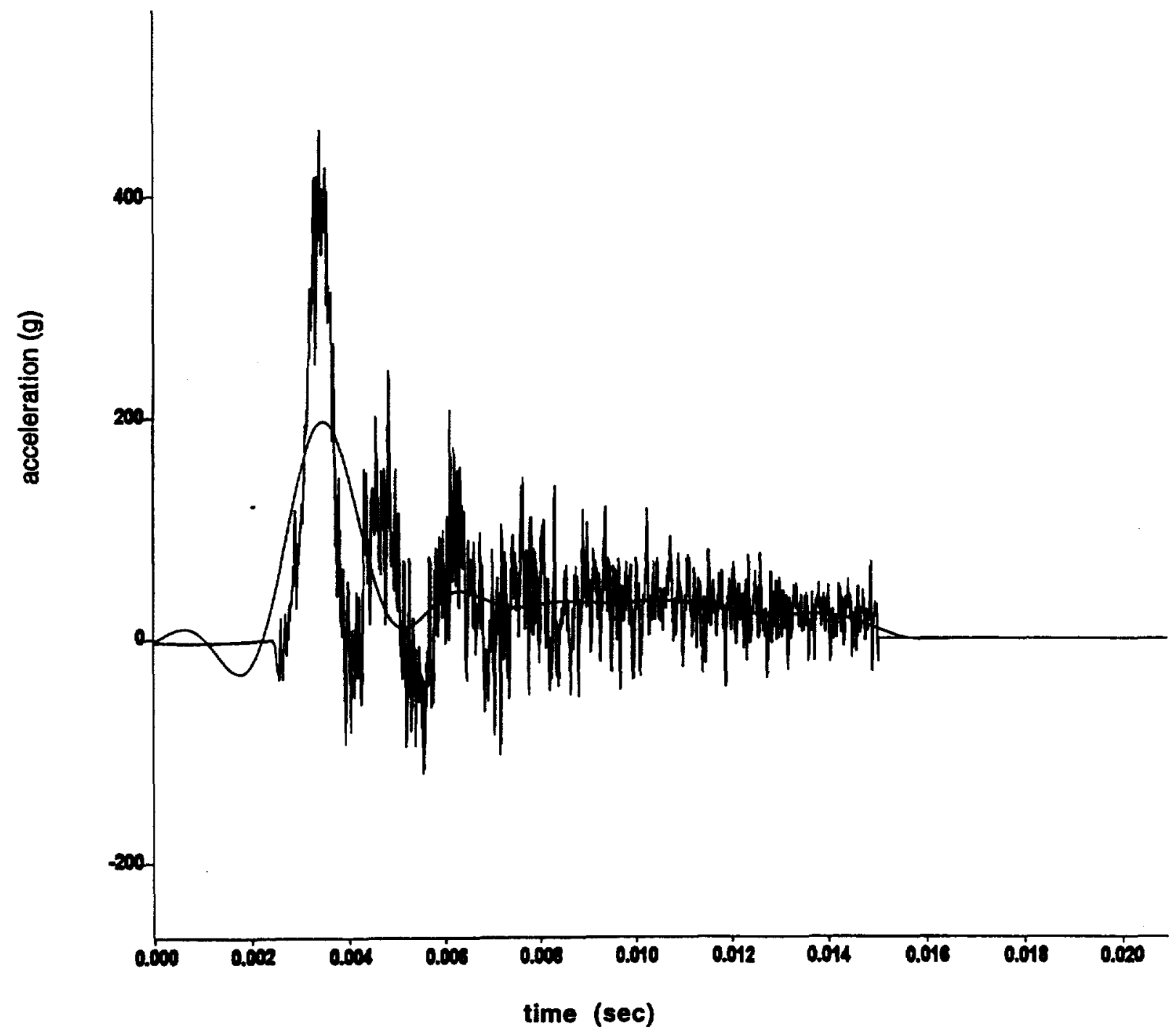

Figure 8. Test \#8, 72" billet side drop, test data from channel A3: unfiltered and filtered at $450 \mathrm{~Hz}$, maximum acceleration $=197.0 \mathrm{~g}$ 


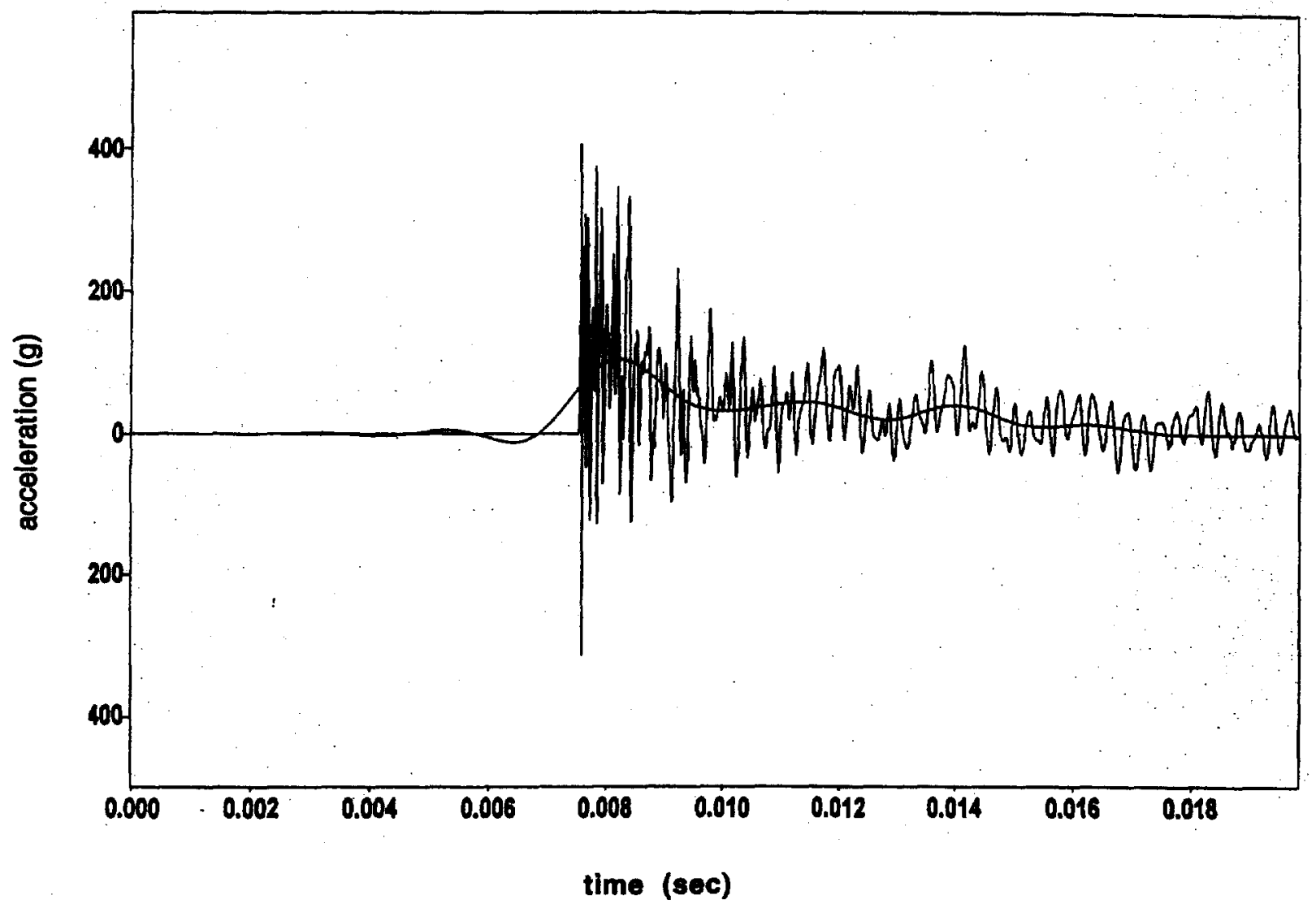

Figure 9. Analysis results for 18" billet side drop, unfiltered and filtered at $450 \mathrm{~Hz}$, maximum acceleration $=104.3 \mathrm{~g}$ 


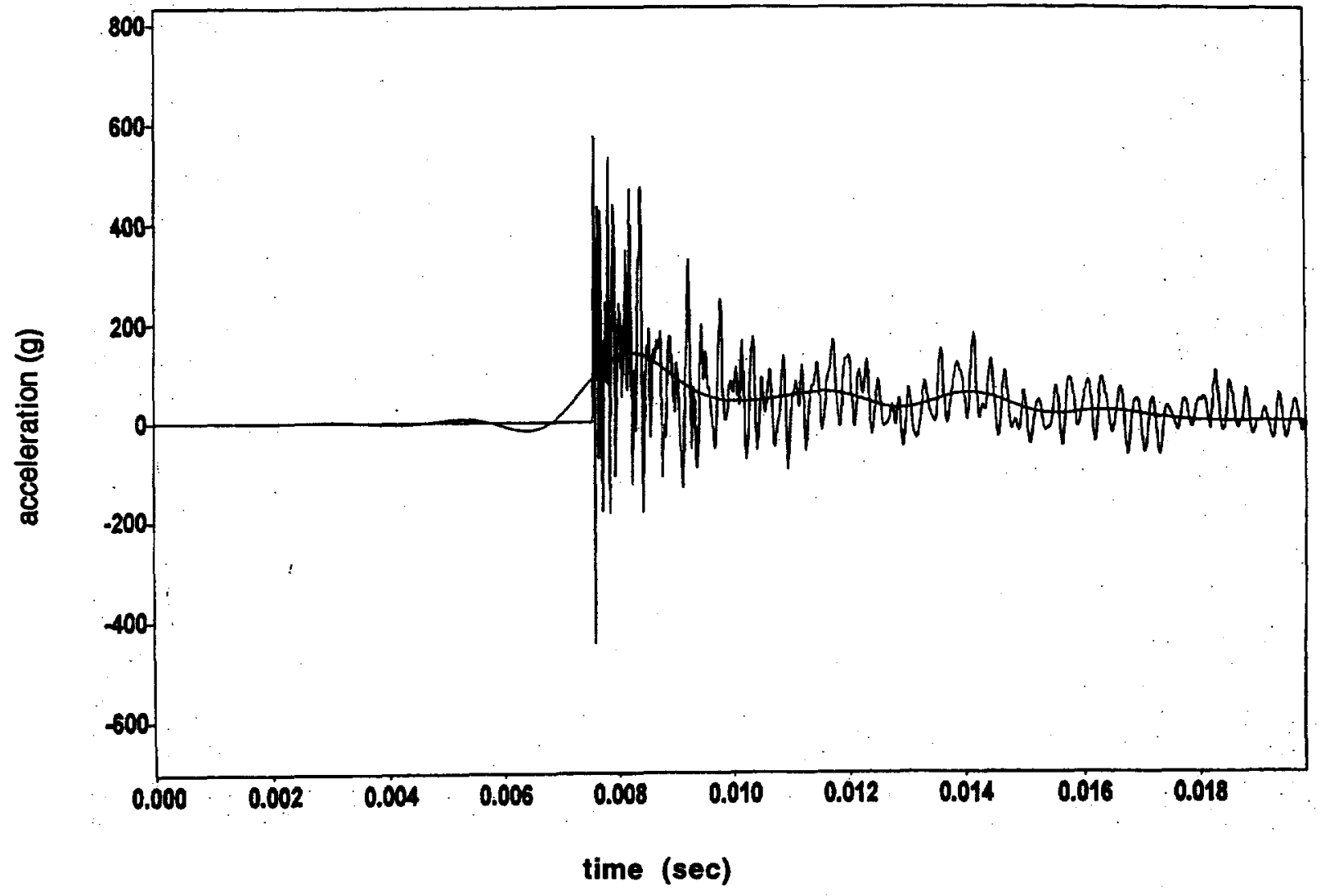

Figure 10. Analysis results for 36" billet side drop, unfiltered and filtered at $450 \mathrm{~Hz}$, maximum acceleration $=139.5 \mathrm{~g}$ 


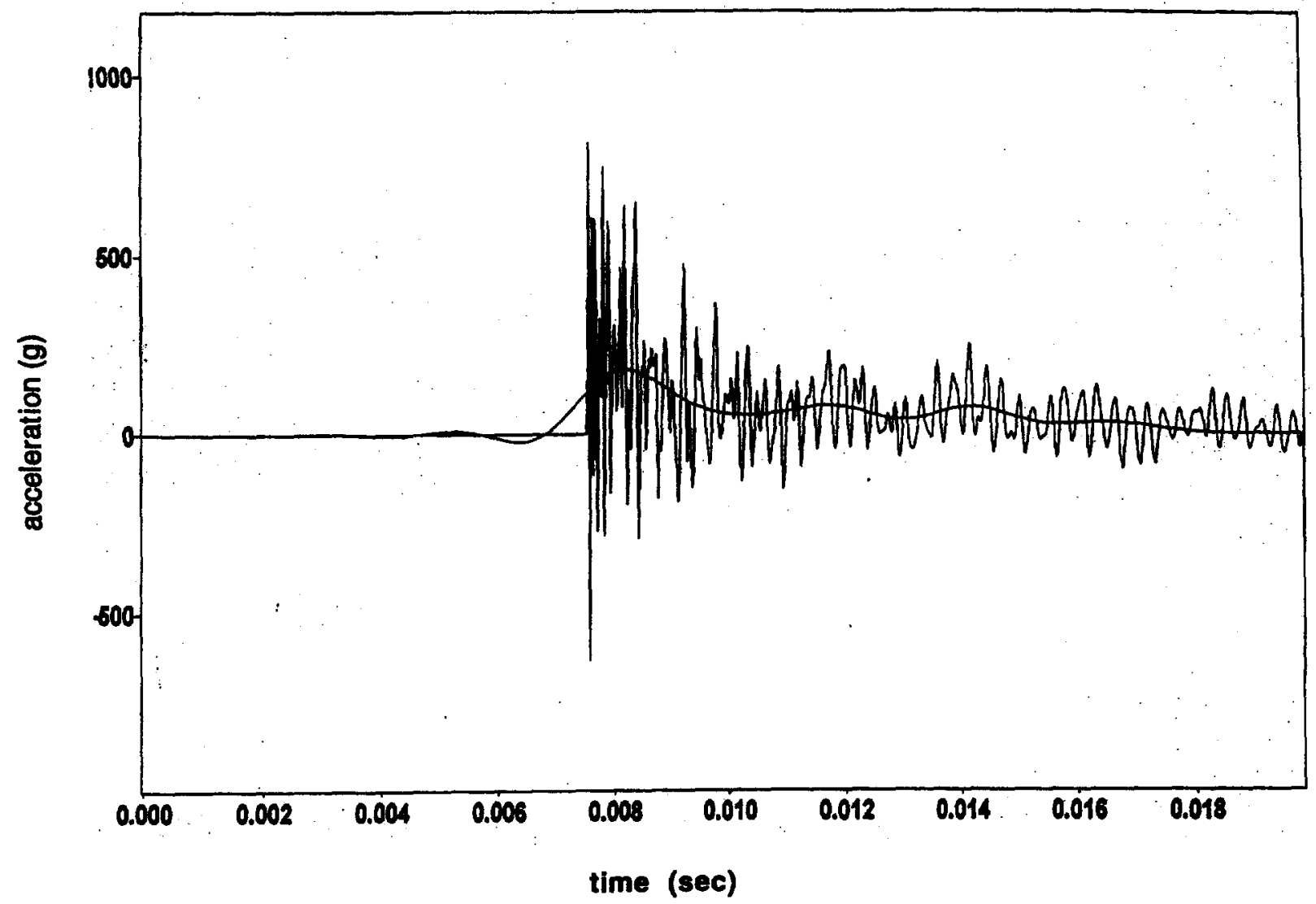

Figure 11. Analysis results for 72" billet side drop, unfiltered and filtered at $450 \mathrm{~Hz}$, maximum acceleration $=182.6 \mathrm{~g}$ 


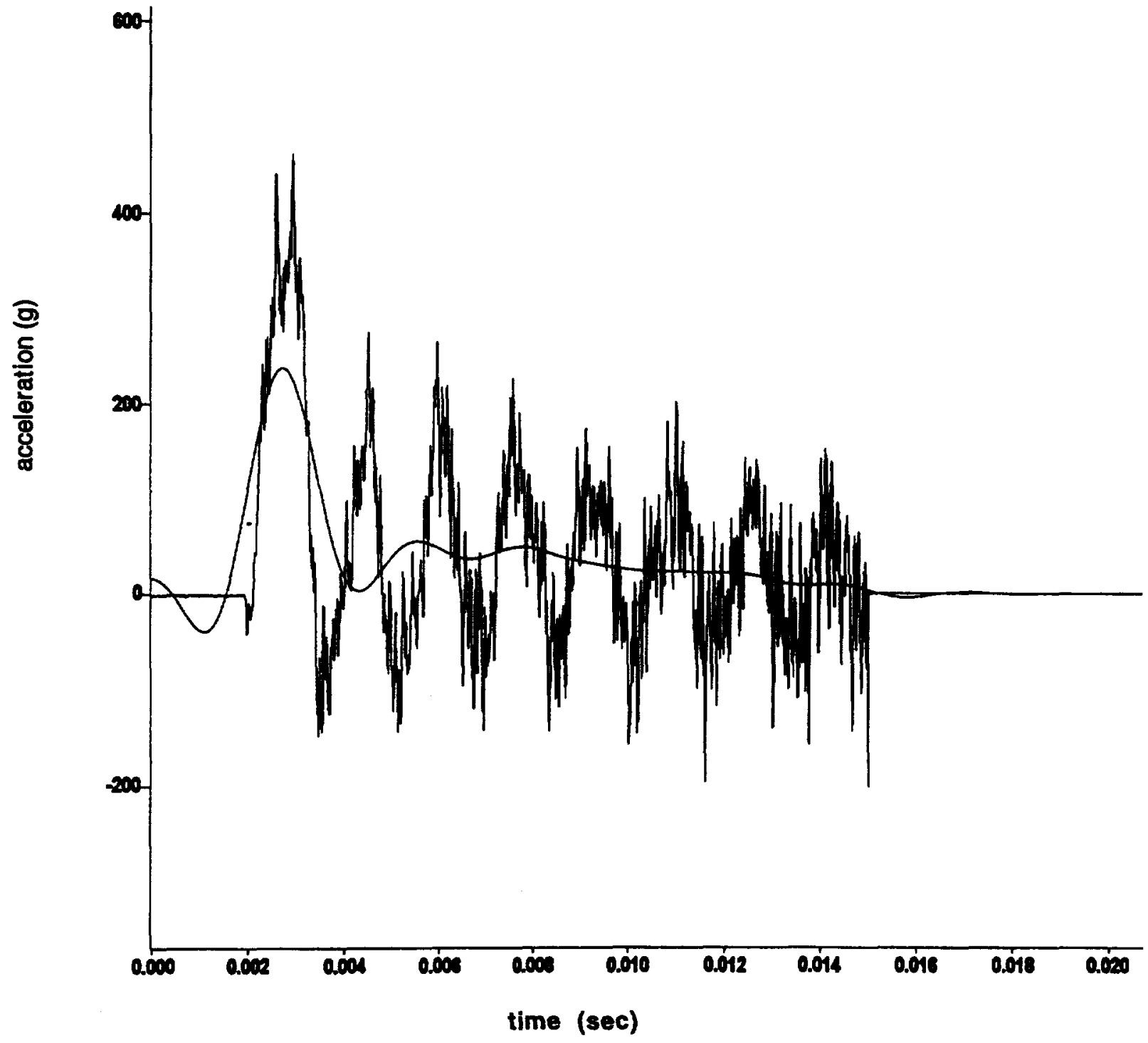

Figure 12. Test \#11, billet tipover, test data from channel A1: unfiltered and filtered at $450 \mathrm{~Hz}$, maximum acceleration $=237.5 \mathrm{~g}$ 


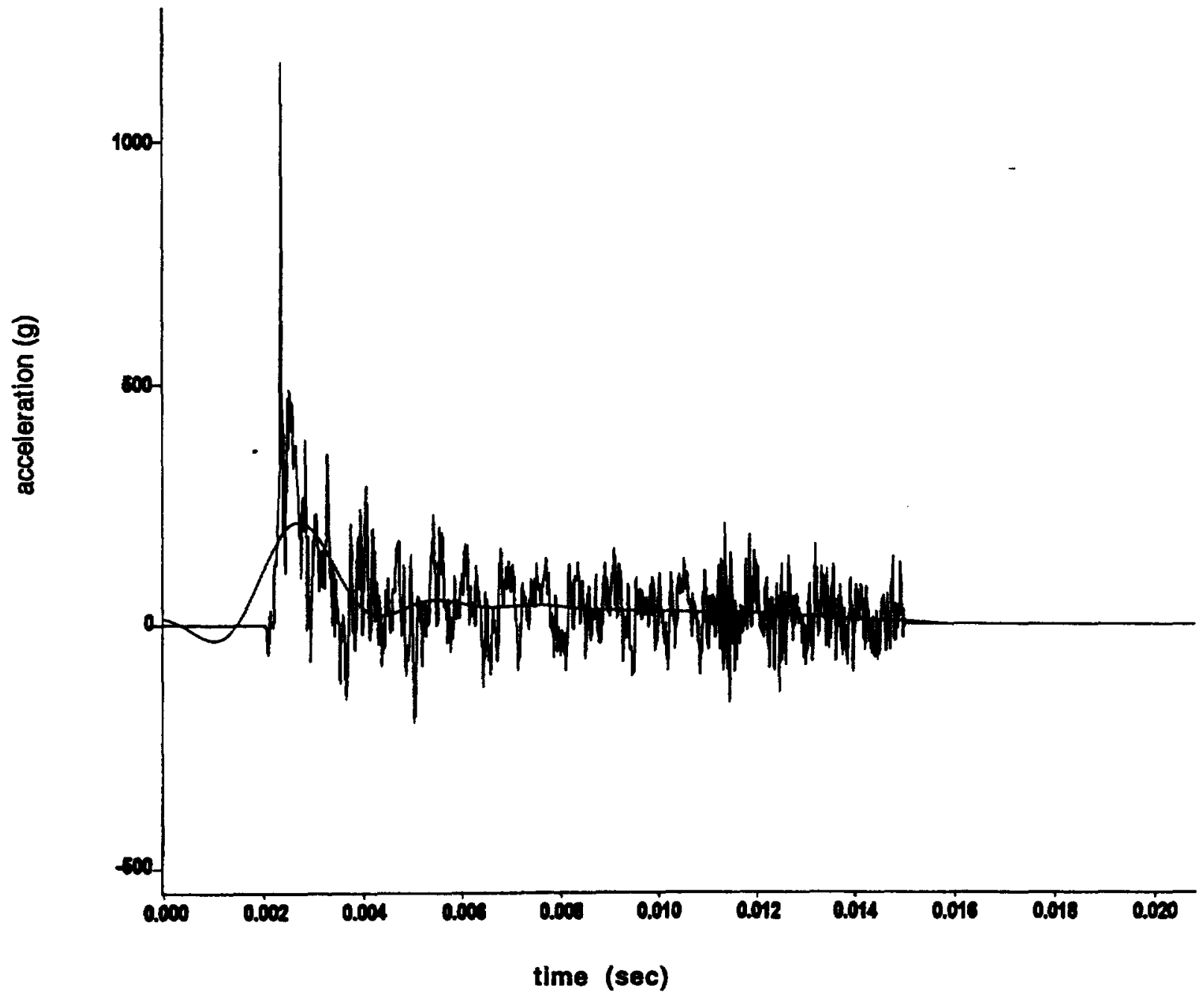

Figure 13. Test \#12, billet tipover, test data from channel A1: unfiltered and filtered at $450 \mathrm{~Hz}$, maximum acceleration $=213.6 \mathrm{~g}$ 


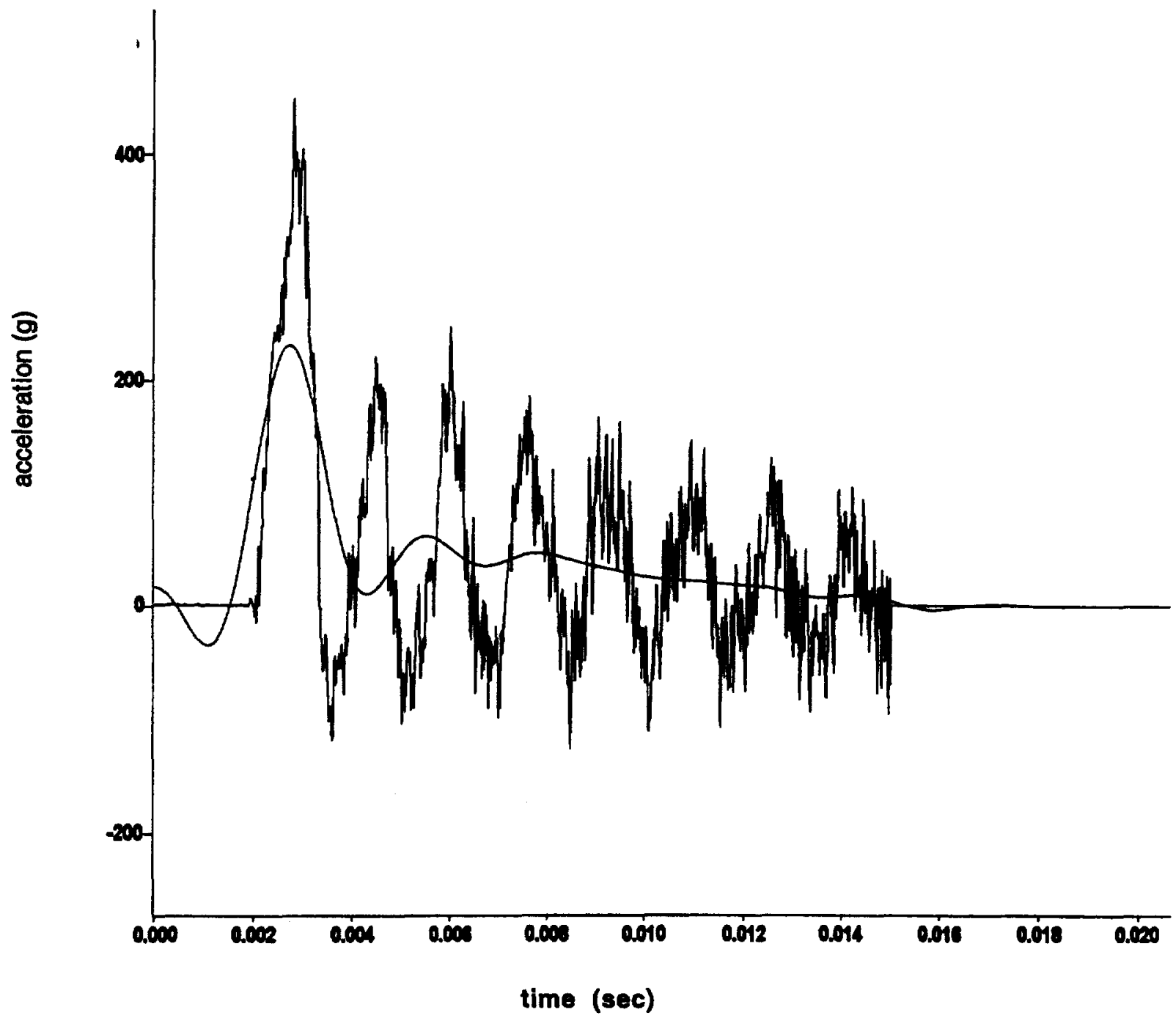

Figure 14. Test \#11, billet tipover, test data from channel A5: unfiltered and filtered at $450 \mathrm{~Hz}$, maximum acceleration $=231.5 \mathrm{~g}$ 


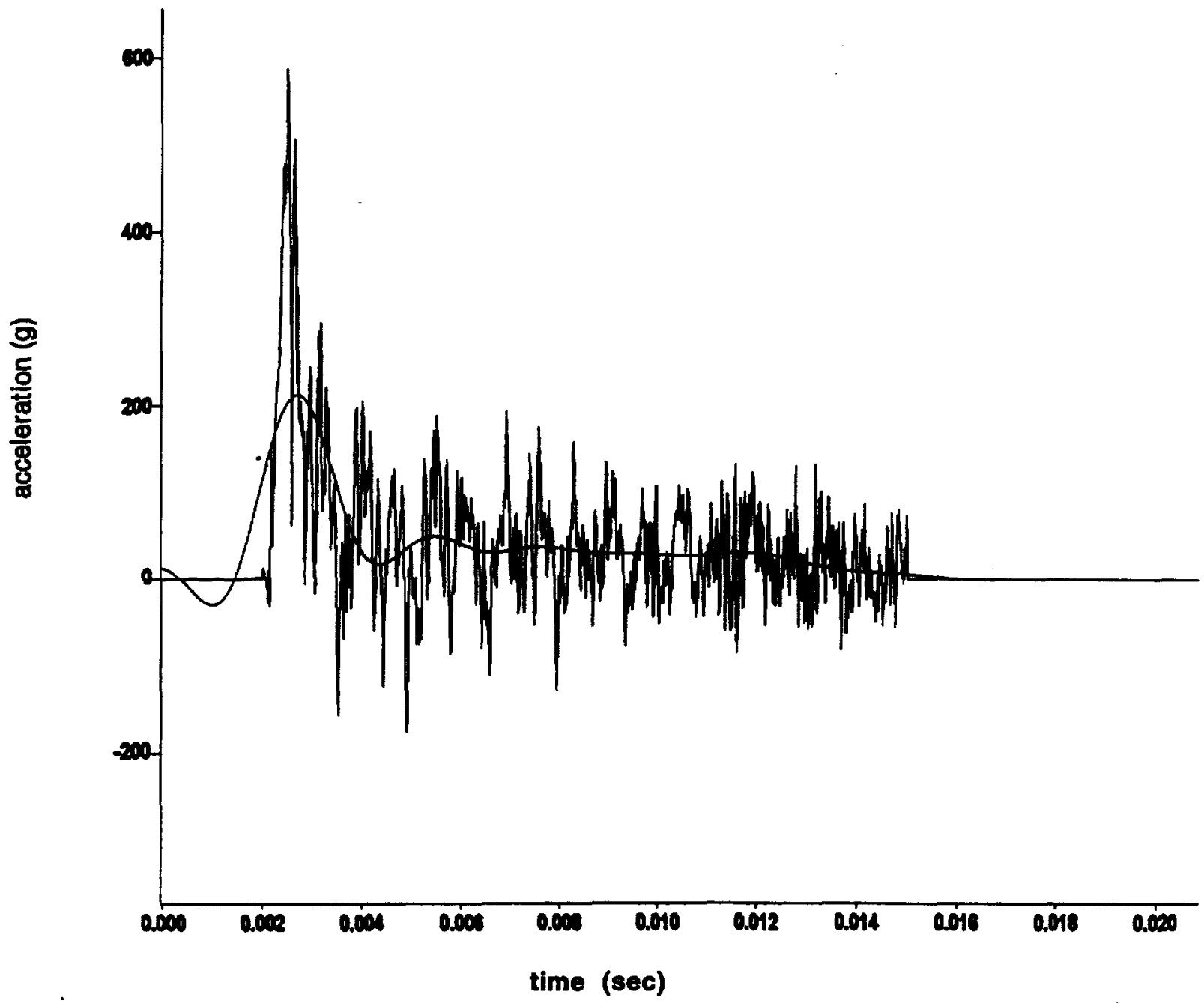

Figure 15. Test \#12, billet tipover, test data from channel A5: unfiltered and filtered at $450 \mathrm{~Hz}$, maximum acceleration $=213.0 \mathrm{~g}$ 


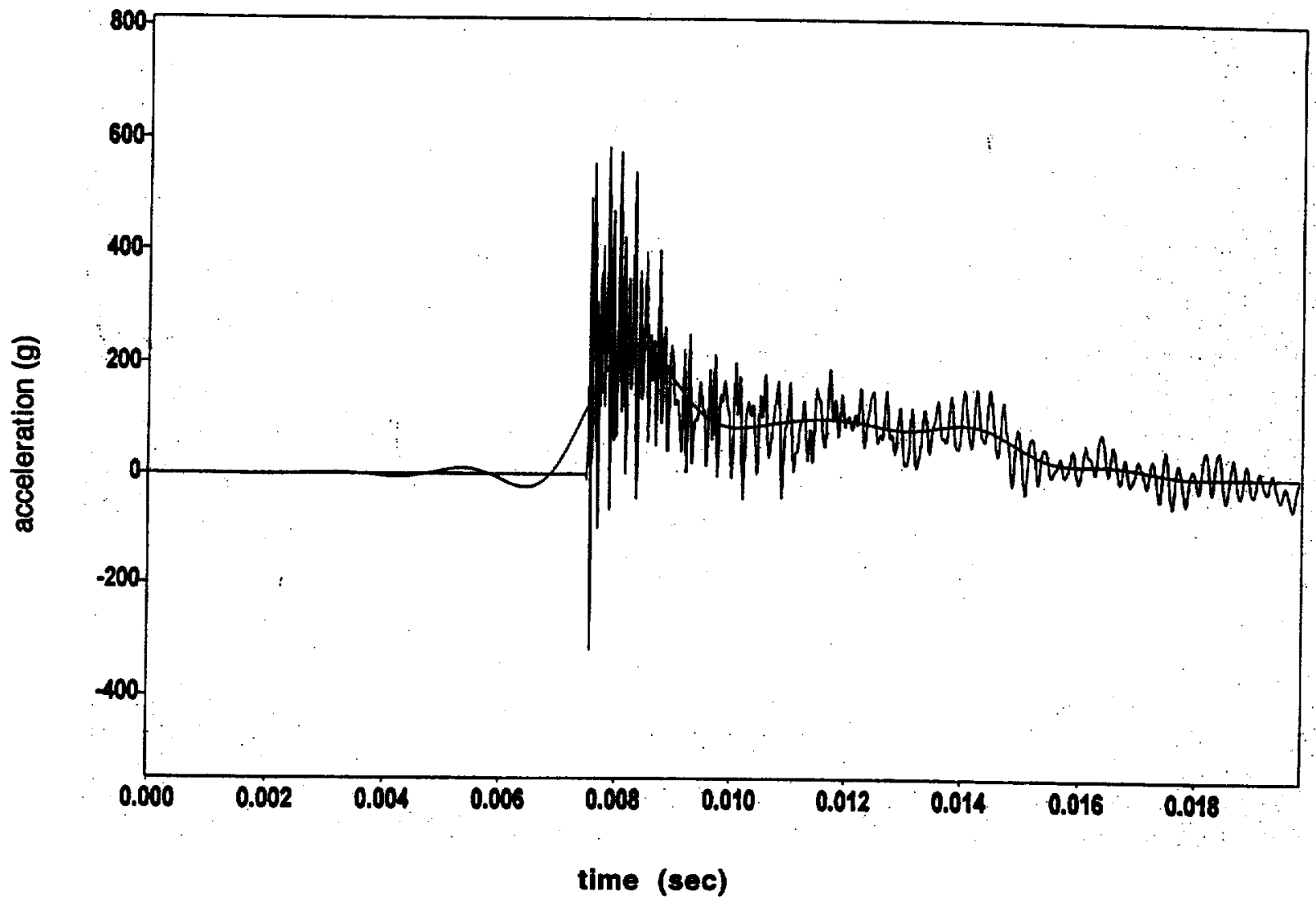

Figure 16. Billet tipover analysis results, unfiltered and filtered at $450 \mathrm{~Hz}$, maximum acceleration $=\mathbf{2 3 3 . 1 \mathrm { g }}$ 

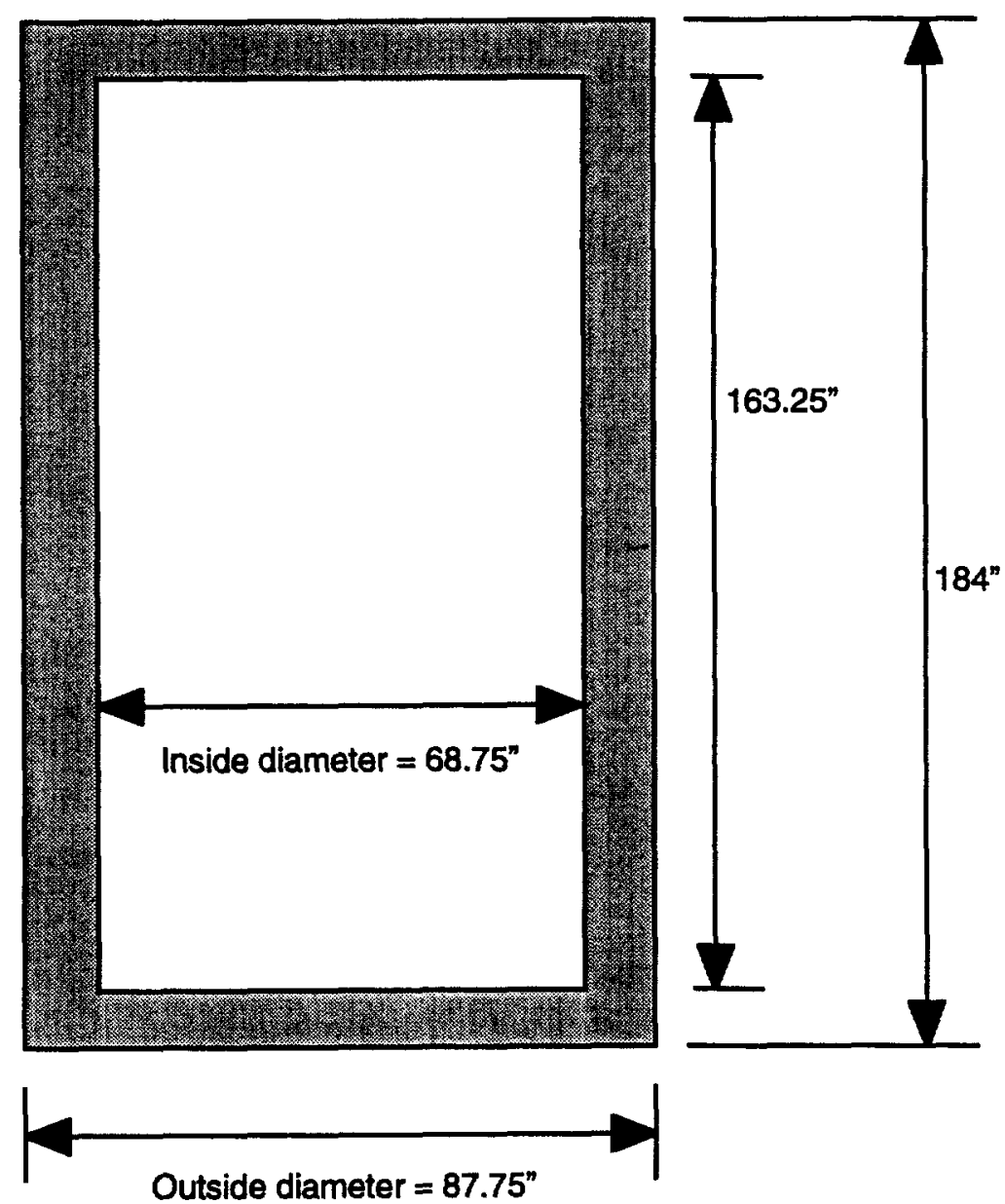

Cask weight $=232,000 \mathrm{lbs}$

Figure 17. Generic cask dimensions 


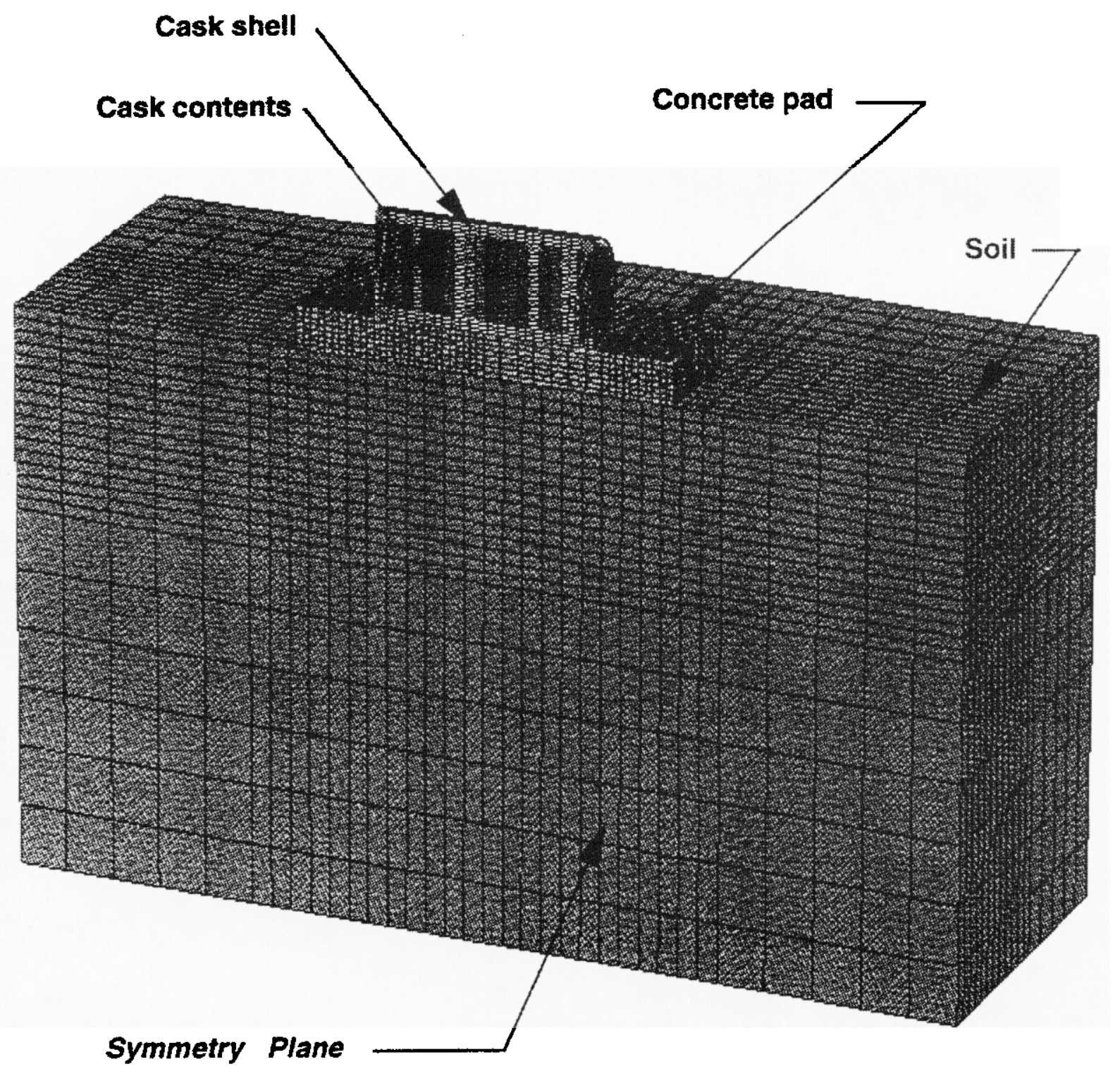

Figure 18. Finite element model of "generic" storage cask, side drop and tipover onto concrete pad and soil 


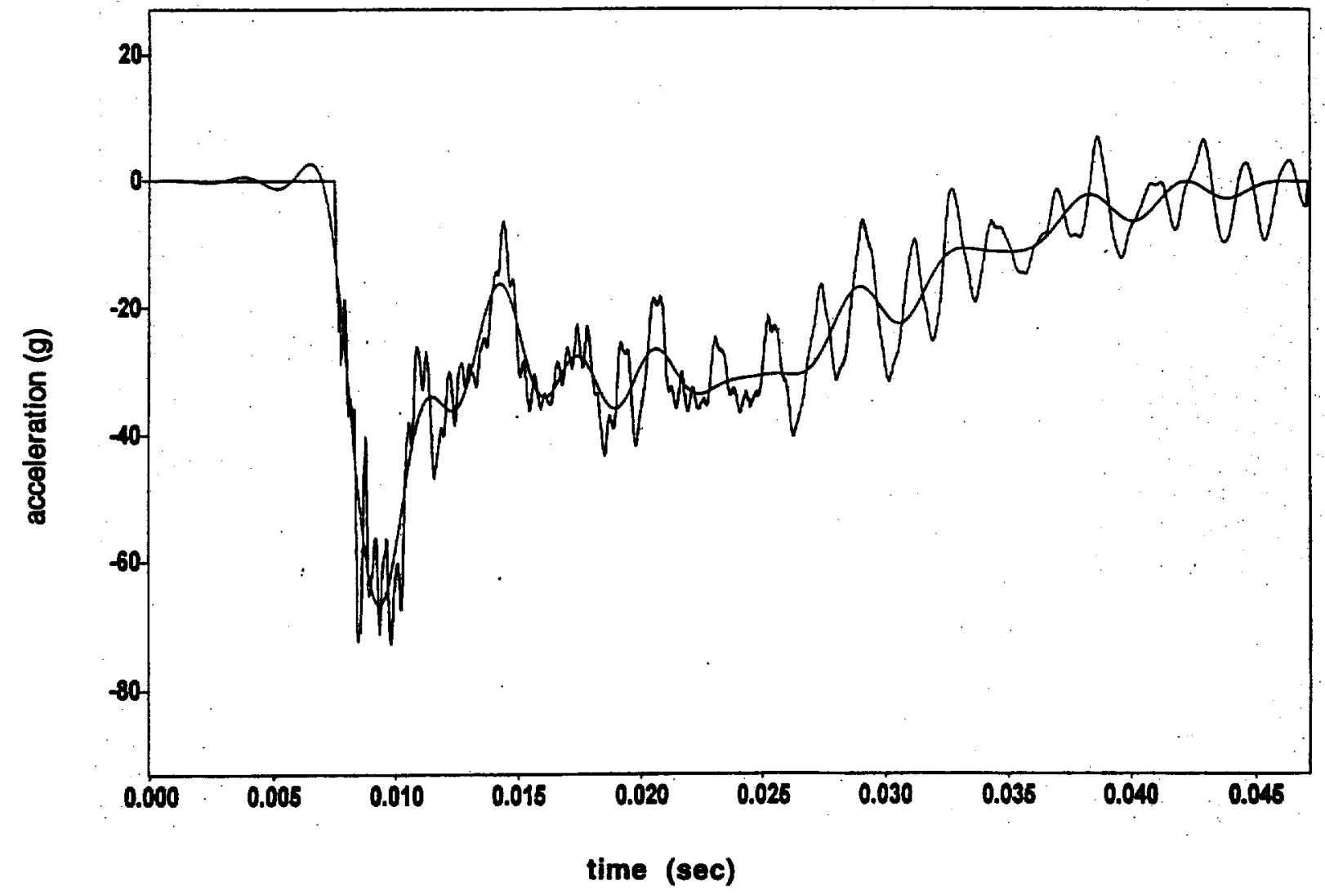

Figure 19. Generic cask tipover analysis results, unfiltered and filtered at $350 \mathrm{~Hz}$, maximum acceleration $=66.7 \mathrm{~g}$ 


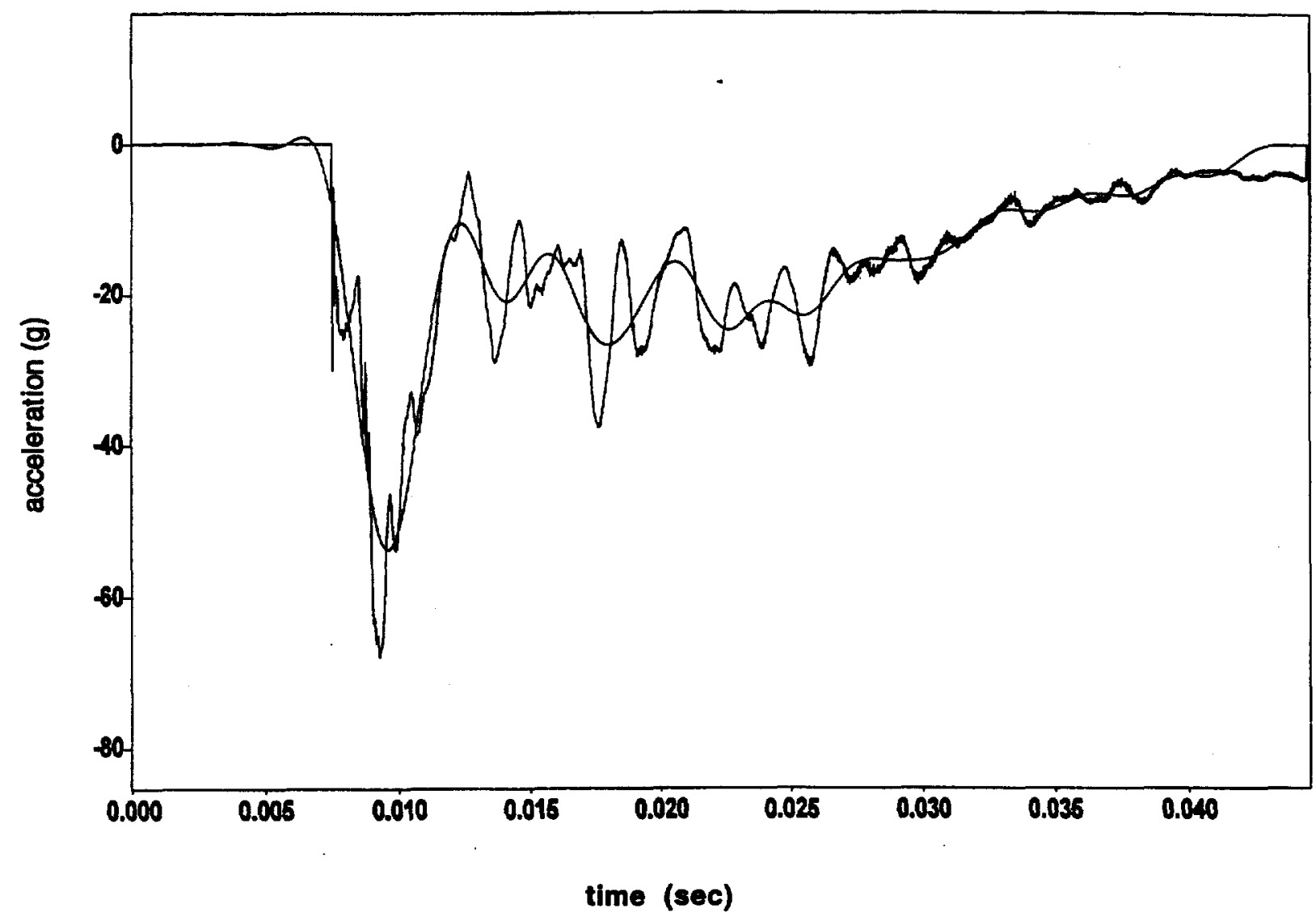

Figure 20. Generic cask 72" side drop analysis results, unfiltered and filtered at $350 \mathrm{~Hz}$, maximum acceleration $\mathbf{= 5 3 . 8 \mathrm { g }}$ 
